\title{
THE THEORETICAL EXPLICATION OF THE FACTORS OF REGIONAL GROWTH AND THE ECONOMIC CONVERGENCE (DIVERGENCE) OF THE REGION
}

\author{
Danijela Despotovic ${ }^{* 1}$ and Slobodan Cvetanovic ${ }^{2}$ \\ ${ }^{1}$ Faculty of Economics, University of Kragujevac, Kragujevac, The Republic of Serbia \\ 2 Faculty of Economics, University of Nis, Nis, The Republic of Serbia
}

For a few last decades, economists have been showing a continuous interest in doing research in the key factors of regional growth and the developmental convergence (divergence) of the region. However, beside the wealth of theoretical and empirical research in the mentioned categories, it is obvious that there is still no generally accepted explication of the key factors of regional growth. The same conclusion can be borne in mind in relation to the existence of the connection between the accepted economic growth of a country and a tendency to increase, i.e. decrease regional inequalities. The paper presents a theoretical explication of a) the key factors of regional growth and b) the phenomenon of developing the convergence (divergence) of the region, five representative theoretical approaches to the regional economy (classical, neoclassical, endogenic, new economic geography and spatial innovation systems). The current economic reality on the global plan which speaks of an increasing regional inequality confirms the accuracy of the theoretical considerations of the representatives of the contemporary theoretical approaches related to the analyzed issues.

Keywords: regional economy, economic growth of region, convergence (divergence) of regional development, contemporary theories

\section{JEL Classification: 011}

\section{INTRODUCTION}

Research in the key factors of economic growth and the development of a region has been present in economic science from the mid-20th century until

* Correspondence to: D. Despotovic, Faculty of Economics, University of Kragujevac, Dj. Pucara 3, 34000 Kragujevac, The Republic of Serbia; e-mail: ddespotovic@kg.ac.rs today (Cvetanović, Filipović, Nikolić \& Belović, 2015). Although, regarding this issue, no necessary unity has been achieved in the attitudes of the theoreticians of the most significant strategies in the regional economy, the approach to their classification into the classical and neoclassical theoreticians, the theoreticians of the endogenic explication of economic growth, the authors of a new economic geography 
and the supporters of the so-called spatial innovation systems is adopted in this paper (Puljiz, 2009). Thereby, the last three theoretical strategies belong to the group of the so-called contemporary theories of regional development. The analysis of the attitudes of the theoreticians who represent the mentioned theoretical strategies in the regional economy shows a change in the focus in the assessment of the most significant factors of regional growth from productive and natural factors towards the factors of knowledge, innovations and networking (Trivić \& Petrov, 2014). The theoretical considerations about the convergence and divergence of the gross domestic product per capita among the regions also differ, depending on the individual researchers' support to the said strategies in the regional economy.

The research subject in this paper is the theoretical explication of the key factors of regional growth and development, as well as the relation between the economic growth of a country and regional inequalities in economic science.

The aim of the paper is to investigate the most significant factors of the economic growth and development of a region and the relationship between the economic growth of a country and regional inequality in significant theoretical approaches to the regional economy from its appearance in the 1950s to date.

In accordance with the subject and the aim of the research, the basic hypothesis of the paper is as follows:

H0: The contemporary theories of regional development accentuate the significance of nonmaterial factors of regional growth

Beside the basic hypothesis, an additional hypothesis is also defined:

H1: The contemporary theories of regional development prefer the attitude about the growing developmental divergences of the region.

In the methodological sense, the paper avoids the explications of the complex quantitative presentations of the significance of the key factors of the economic growth of countries and regions, as well as the relationship between economic growth at the national level and the regional inequalities that are abundant in the investigation of these phenomena in relevant economic literature. An attempt was made to explain the key factors of the economic growth of the region and the relationship between the economic growth of a country and regional inequalities in the light of the divergent attitudes of certain theoretical standpoints in the regional economy related to these two questions by applying a descriptive analysis and graphic explications.

Beside the Introduction, the Conclusion and the List of References, the paper is also structured into the following three sections: Regional Development and Regional Inequalities; The Factors of Regional Growth in Economic Theory, and The Non-linear Character of the Relationship Between the Economic Growth of a Country and Regional (In)Equalities. The first section presents a general survey of the factors of regional development and the attitudes of the most significant representatives of certain approaches in economic theory regarding the relationship between the economic growth of the country and tendencies in the movement of regional (in)equalities. It points out that, on a purely conceptual plan, the regional policy is aimed at the optimization of the two basically contradictory objectives - the acceleration of economic growth, on the one hand, and a decrease in the developmental (in)equalities of regions, on the other. The second section presents the concepts of the supporters of significant theoretical strategies which the contemporary regional economy is based on (the classical strategy, the neoclassical economic school, Canesian economic thought, the theory of economic development, the endogenic theory of growth, the so-called new economic geography, an approach to spatial innovation systems) regarding the key factors of the economic growth of the region, whereas the third section presents a critical analysis of the attitudes of these theoretical strategies related to the mutual relationship between the growth of a country and an expression of regional (in)equalities. 


\section{REGIONAL DEVELOPMENT AND REGIONAL (IN)EQUALITIES}

The studying of the factors of regional growth and the economic convergence (divergence) of a region is possible from different theoretical approaches (Figure 1). R. Capello and G. Perucca (2015) think that the postulates of the theory of location and the theory of regional growth and development are of decisive importance in the procedure of regional growth assessment factors. The key promoters of regional development differ depending on the adopted concept of regionalization. The efficiency of interregional allocation and intraregional multiplication mechanisms have a predominant influence on the productivity of the factors and the magnitude of income multipliers (Stimson, Stough \& Nijkamp, 2011, 10).

During the 1960s and the 1970s, the regional economy in the most developed countries of the world was focused on the consideration of the significance of specialized production and the increasing role of the country in the activation of regional growth. In the 1980s and the 1990s, certain regions were rapidly being developed, becoming predominant in the world economy under the influence of globalization and strong technological development.

J. G. Williamson (1965, 3-45) was among the first to write about the relationships between the size of regional inequalities and the achieved level of the development of a country. J. G. Williamson (1965) presented the results of his research in the form of regulation, by which the growth of the gross domestic product per capita causes an increase in the beginning, and then, after a certain level of the gross domestic product per capita has been achieved, it leads to a decrease in regional inequalities (Figure 2).

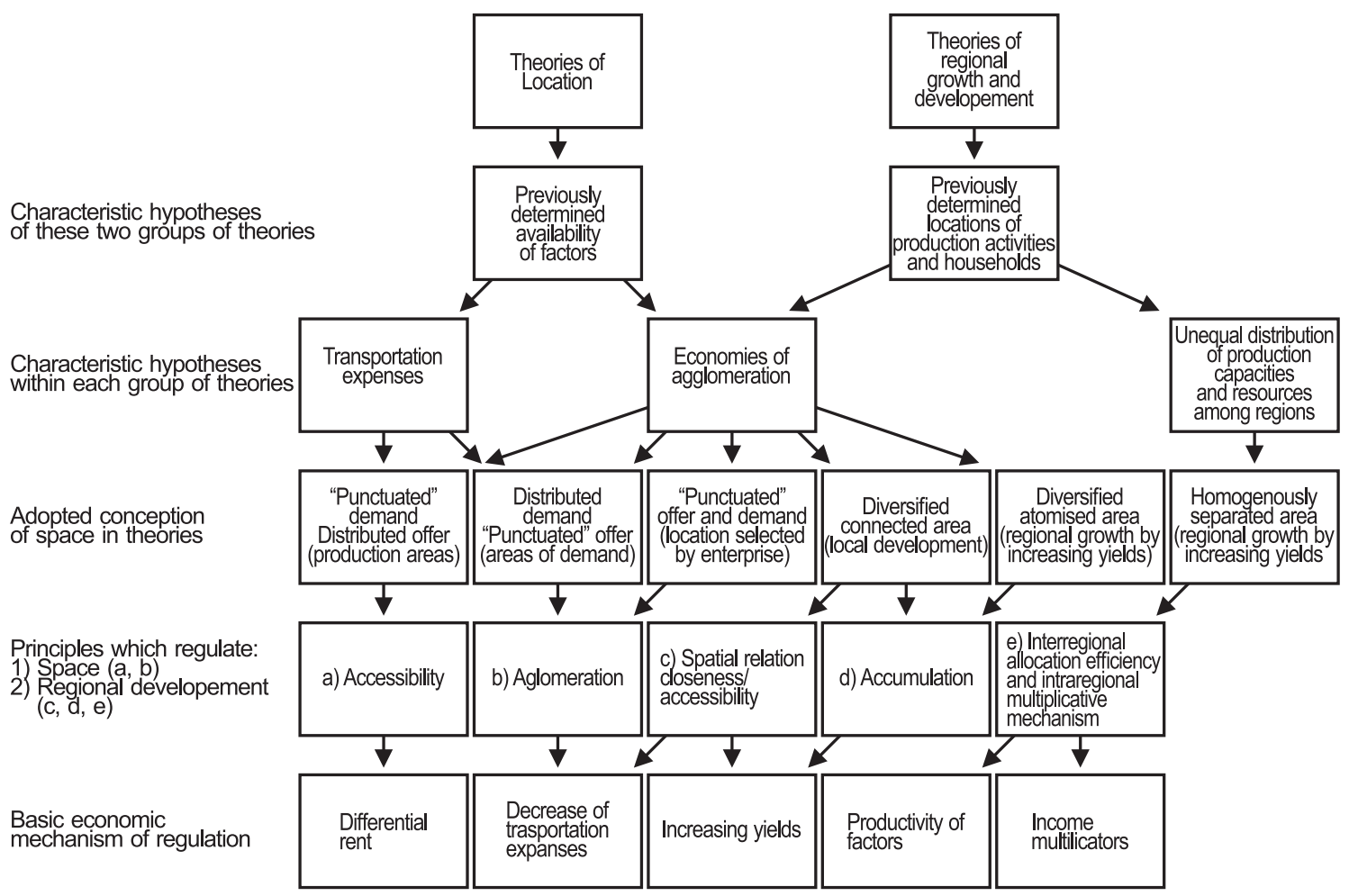

Figure 1 The development of a regional economy 


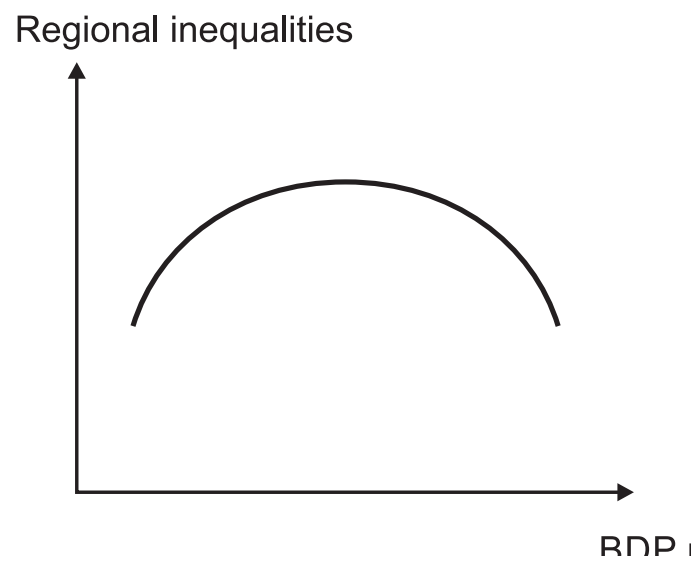

Figure 2 J. G. Williamson's reverse U-curve

Source: Davis \& Weinstein, 1999, 5

The explicated idea of J. G. Williamson's (1965), related to a nonlinear connection between the achieved level of the gross domestic product per capita in the observed country and regional inequalities in the form of the reverse letter $\mathrm{U}$ was completely taken from $\mathrm{S}$. Kuznets (1955), who, after having conducted a thorough empirical research study, came to a conclusion that, at the early stages of economic development, a tendency of increasing inequalities in the distribution of the gross domestic product appeared, which declined at the higher levels of the economic development of the country. However, independently of the attitude related to the originality of the presented idea, the fact that J. G. Williamson (1965) drew attention of regional economists to the nonlinear nature of the relation between the levels of regional inequalities within certain countries and the size of the gross domestic product per capita has appeared to be an extremely significant standpoint in the consideration of the regional aspects of economic growth and development in the last fifty years. Because, at purely conceptual level, the regional policy is aimed at the optimization of the two, basically contradictory, objectives - the acceleration of the economic growth of a country, on the one hand, and a decrease in the developmental inequalities of its spatial units (regions), on the other. The creation of economically developed regions capable of being integrated into global economic courses is the primary aim of the management of regional development (Maskell, 2000).

\section{ON THE FACTORS OF REGIONAL GROWTH IN ECONOMIC THEORY}

In economic theory, classical literature on economic development most often implies the research realised in the mid twentieth century, when consideration of the most significant factors of economic growth and development of a region and the phenomenon of regional inequalities prevailed (Puljiz, 2011). Bearing in mind, conceptual bases of the theories of regional development, the works of F. Pérroux (1955), G. Myrdal (1957) and A. O. Hirschman (1988) are primarily classified here.

According to the views of the classical theoreticians of regional development, the three key factors of the economic growth of a region are physical capital, natural capital and human capital. In relation to the second issue discussed in the paper, they decisively support the opinion of expressing regional inequalities.

The best-known doctrine on the essential issues of regional development is certainly F. Pérroux's theory of the polarities of growth (1955), which has become nearly synonymous to the theory of regional development. Similarly to the other classical theoreticians who considered the issues of regional growth, F. Pérroux (1955) starts from the fact that development does not take place equally and concludes that development is concentrated in certain spatial foci, i.e. it polarizes. F. Pérroux's positions his analysis in a real, polarized area, with considerable changes in the suitability of locations to attract investments and accelerate development (1955). F. Pérroux (1955) differentiates the wave of polarization where these polarities of growth are formed, from the wave of dispersion, when the developmental stimulation of the polarities of growth is transmitted to their zones of influence. The intensity of the waves of dispersion is a criterion for measuring the strength of the very polarity of development.

One of the best-known explications of the problems of the polarities of growth in a regional economy is G. Myrdal's hypothesis of circular and cumulative causality (1957). According to this author, the factors 
of the economic growth of a region (primarily human capital) move to faster-developing regions and create the growth of a profit and distance from more slowly growing regions. The stated process is often noticed in developing countries.

In his research, A. O. Hirschman (1988) especially points to the following two reasons of lagging of economically less developed regions in relation to more developed regions. The first refers to the phenomenon of extrusion of an enterprise from less developed areas when faced to competitiveness of the enterprises from economically more developed regions, and the second relates to migration of welleducated individuals from less developed regions to economically developed regions.

Neo-classicists think that the growth of the value of production at the national and regional levels is a result of an increase in physical capital, an increase in labor and the perfection of technology (Barro \& Sala-i-Martin, 2004). They assume the homogeneity of the area where each point has an equal locational convenience. The countries, i.e. regions, which do not invest in physical capital and have a lower rate of population growth and which improve their technology relatively more slowly, have per se lower economic rates in comparison to the countries, i.e. regions, that invest in the growth of physical capital relatively more, have a more pronounced rate of population growth and more intensively improve technology in the widest meaning of the word (Figure 3).

The neoclassical explications of the philosophy of the economic growth of a region start from the assumptions related to the expression of the economy of scope, the behavior of economic subjects in accordance with the prices established on perfectly competitive markets, the absence of extremities, the existence of technological changes in the exogamic character. They completely neglect the significance of institutional factors and a possible stimulating influence of the regional policy on the economy and growth (Kurz \& Salvadori, 2001). According to the logic of neoclassical economists, the economic growth of countries, i.e. regions, in the short and medium period is based on the use of a greater quantity of physical capital and work. In the long run, the economic growth of a region is exclusively possible exclusively owing to the category of technological progress.

Endogenic theory claims that the dynamics of the economic growth of countries and regions is mostly determined by the character of the key attributes of the economic system, i.e. the economic policy of a country and the developmental policy of a specific region (Todaro \& Smit, 2015).

Numerous versions of the endogenic explanations of economic growth point to the significance of the

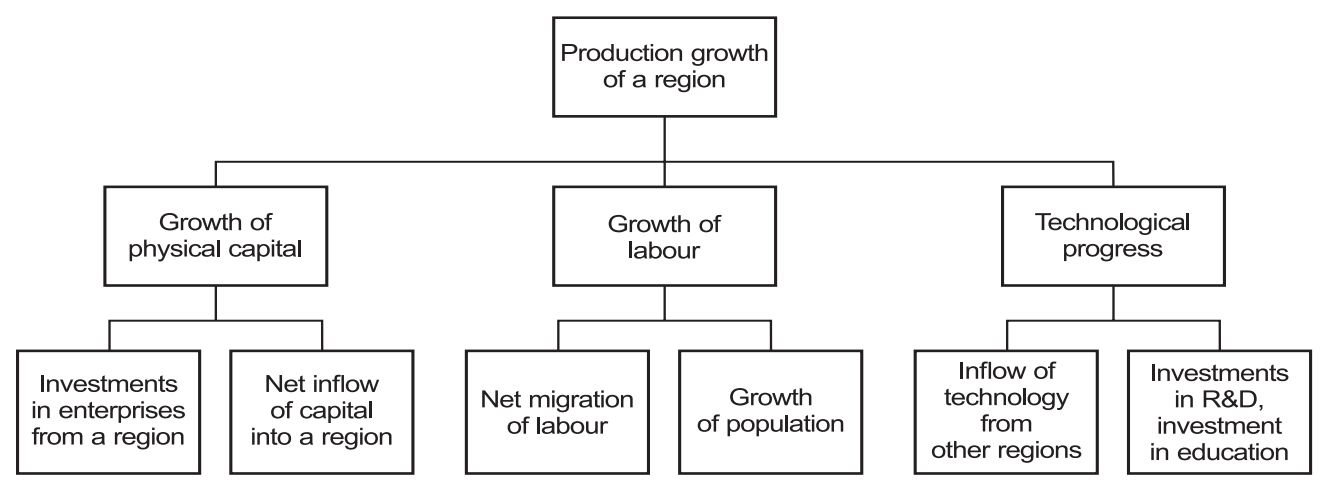

Figure 3 The factors of regional economic growth in the interpretation of neoclassical economists 
existence of corresponding institutional arrangements (Cvetanović et al, 2015). Some of them claim that the "location of industry can be of decisive importance for regional development and that the synergic effects of locations are important for technological and other influences of knowledge spillovers and innovations." (Dragičević 2012, 20). There is a consensus in the regional economy that the endogenic theory of growth is their most important conceptual framework (Vazquez-Barquero, 2002). This judgement was additionally emphasized by the global crisis in 2008 (Jakopin, 2012).

The endogenic theory of growth rejects the neoclassical view of the three basic factors of the economic growth of a region. In those economists' opinions, in addition to physical capital, labor and technology, production, human, social, creative and economic capital is essentially important for longterm sustainable regional growth (Figure 4).

By increasing the above-stated five forms of capital in less-developed regions, a potential for development and absorbing the stimuli and the developmental impulses that come from economically developed regions is created. If they remain rejected for any of the stated forms of capital, less-developed regions will probably remain underdeveloped, even in the conditions when they are allotted certain funds for development.

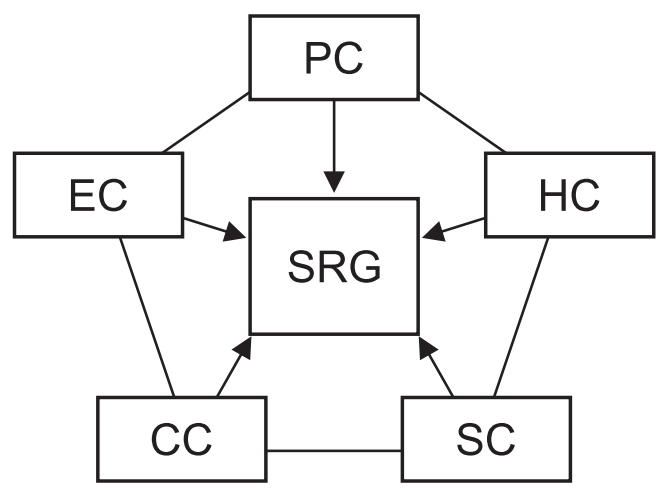

Figure 4 The factors of the economic growth of a region in the interpretation of the supporters of endogenic theory

Source: Stimson, Stough \& Nijkamp, 2011, 10
The significance of production capital (PC) originated from the neoclassical theories of growth, which imply that production is predominantly determined by the traditional factors of production, labor and physical capital. In the literature on regional development, physical capital is most often found under the name of capital goods, whose key characteristic is their being an output in the previous and an input in the subsequent process of production. The most important components of physical capital are production equipment (machines, tools etc.). The significance of physical capital in starting the economic growth of a region is determined by its structure, the intensity of increasing and the efficiency of use. The infrastructure is a special segment of physical capital.

Human capital (HC) is included in the central elements of the contemporary theory of economic growth. The most significant components of human capital are the educational level and the health status of the population, the motivation of people to work and develop (Ulrich, 1998; F. Luthans, K. W. Luthans \& B. C. Luthans, 2004). An increase in human capital leads to the growth of the gross domestic product of countries and regions (Lucas, 1988). The importance of the investment of human capital is recognized in contemporary economies, especially in the conditions of an overall application of scientific results to the production process, the intensive development of new technologies, the improvement of the forms and methods of management and the organization of production. In the contemporary conditions of production, education, skills and knowledge are certainly the key components of the productivity of an individual, regions and the economy in general (Cvetanović \& Despotović, 2014). Knowledge as a component of human capital shows the abilities to unlimitedly increase and be used without any limits. Therefore, the categories such as the productivity of the research and development sector, the cognitive capacity and the application and diffusion of knowledge are becoming increasingly important (Lundvall, 1992; Jones, 2004).

Social capital (SC) is the capital of cooperation, interactive acting, mutual confidence and help of people in economic processes. It cannot be in a 
private ownership and has the attributes of a public good. It includes the institutions, relationships, attitudes and values that manage interpersonal interactions contributing to economic and wider social development. It is mostly a result of the legal, political and institutional ambience, where economic participants function, i.e. perform their functions and realize their aims. It defines the economic benefit of a society, acquired owing to communication, cooperation and trust between single subjects in the observed social-economic environment. It refers to the capital of the permanent, and to a certain extent institutionalized, relationships between the individuals and organizations that stimulate the creation of economic values. The attitudes that only the participation of people in formal organizations leads to the creation of social capital are found in the literature, but diametrically opposite ideas are often found, too, where the minimum participation of people in social movements is a component of social capital. J. S. Coleman (1988, 95-120), as one of the creators of social capital, defines this category through its functions. He thinks that social capital provides individual success, since individuals benefit from it. It is a special form of a public good potentially at the disposal of everybody included in the system of social connections and relationships. By R. Putnam $(2008,20)$, social capital consists of the attributes of the organization of a society such as confidence, norms, as well as the most diverse networks that can improve social efficiency through coordinated actions.

Creative capital is fundamentally important for the economic dynamics of a region (Florida, 2002; 2004). R. Florida's identification of a creative class among "people who add economic value through their creativity" (2004) goes further than the approaches based on the traditional indices of human capital as a factor of economic growth. R. Florida (2002) develops the theoretical model by which the presence of a creative class in any position leads to the improvement of the local "creativeness" that results in growing innovativeness and the affirmation of technologically intensive production sectors. He claims that creativity is a result of "social interaction", "authenticity" and "identity", which together generate the "power of ambience" and the resulting economic dynamics at the regional level. The idea that interaction between individuals leads to the positive effects of growth is normally in accordance with comprehensive literature on learning and knowledge spillover on regional labor markets.

Ecological capital (EC) consists of amenities in a region. An ecologically clean environment, the existence of diverse programs for recreation, sports, culture, education, etc. considerably increase the innovative potential of a region, thus affecting the development of the capacity for the sustainable growth of a region.

The explanation of the key factors of economic growth in a region, given by endogenic theoreticians, is a significant qualitative step in comparison to the predominant attitudes in regional geography. The long and short of it is that the endogenic theory of regional development "shows threefold change of the paradigm when strengthening the endogenic abilities of regional growth: from developmental factors to innovative factors, from 'hard' to smooth', which are impalpable - local synergy among the participants, the positive practice of management, a high level of human capital and assets based on knowledge - from a functional to a cognitive approach" (Molnar, 2013, 49).

A step forward in the explication of the key factors of the economic growth of a region and especially the expression of the developmental misbalance during the last twenty years is found in the models of a new economic geography. They started to develop intensively after P. Krugman's paper (1990, 483-499) was published in 1991. In the 1990s, an increasing number of reference papers in this domain appeared (Venables, 1996; Fujita, Krugman \& Venables, 2001). At the end of the twentieth century and at the beginning of the twenty-first century, the literature on the new economic geography was especially enriched by J. Baldwin and R. E. Caves (1997), G. I. Ottaviano and J. F. Thisse (2005), K. Behrens and J. F. Tisse (2007) and many others. According to the approach to the new economic geography, the basic factors of the economic growth of a region are transportation expenses, externalities and a profit from invested assets, since certain enterprises select a specific location on that basis. 
In the 1980s and the 1990s, a series of the theoretical concepts of regional growth and development appeared, based on the innovations as the key factor of the economic growth of a region (Puljiz, 2011). In the literature, these concepts can be found as under the name of "industrial clusters", "innovative milieus", "self-teaching regions".

Their territorial coverage is different and goes from relatively small (industrial clusters) to far larger territories (self- teaching regions). These concepts can be found under the mutual name of spatial innovation systems (innovation hubs) (Figure 5) (Cheshire \& Malecki, 2004).

Spatial innovation systems include mutually related enterprises in certain sectors together with the corresponding suppliers and the service sector, as well as a series of accompanying institutions, including universities, institutes, laboratories, professional associations and agencies.

In economic literature, industrial clusters have been described as a form of a spatial innovation system and an increasingly significant stimulator of regional competitiveness. In fact, clusters mark a specific approach to the networking of industrial, public and private institutions and the industrial sector. They contribute to the improvement of industrial production by connecting participants in the production chain of the production sector. Briefly, they are a specific platform for cooperation between various subjects, aimed at improving competitiveness thanks to the functional connections and possibilities of the dissemination of knowledge and experience in order to efficiently realize new business attempts and the promotion of manufactured goods on national and international markets. By networking interested parties in the realization of various business attempts, it can be possible to contribute to the strengthening of the competitiveness of business subjects, the improvement of regional competitiveness and a more balanced regional development.

Industrial clusters are the geographical concentrations of production forms, established in order to decrease expenses, the use mutual channels of supply and distribution, marketing strategies, etc. The motives for the business pooling of a larger number of productive enterprises in a certain territory are numerous. They can be: mutual appearance on markets where it is hardly possible for companies to succeed independently; the joint use of highly specialized services, professional labor, rarely used equipment, etc. A cluster of one industrial branch is characterized by the whole chains of functionally connected activities, whereby each activity means an additional value, from suppliers to final products

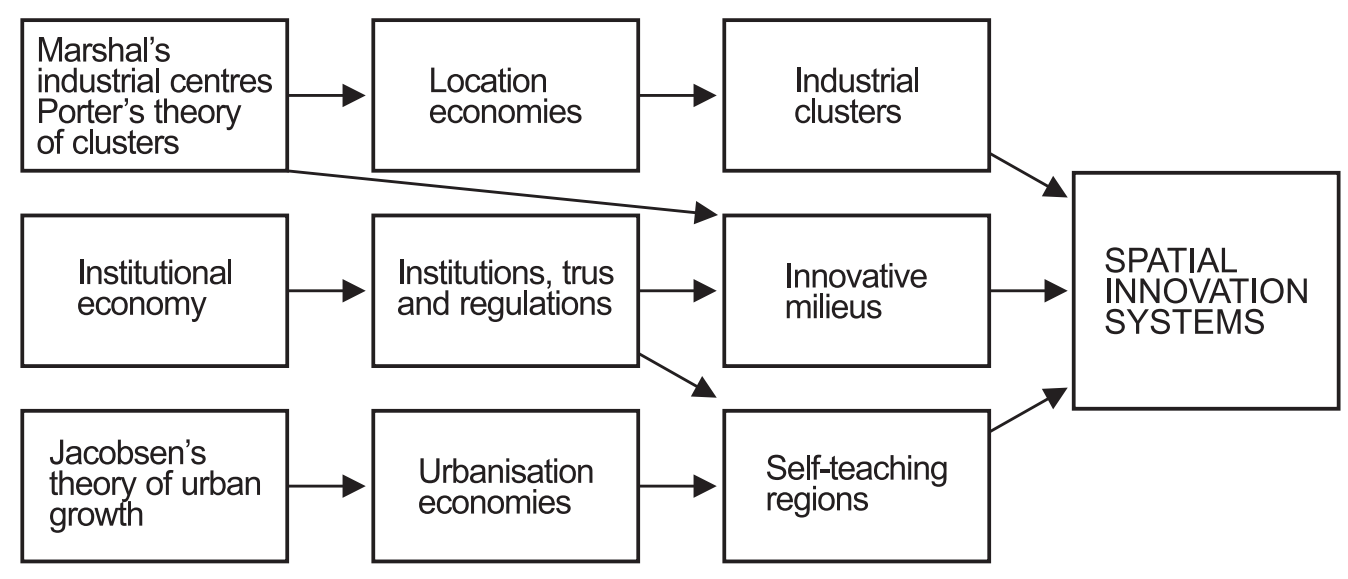

Figure 5 Spatial innovation systems 
and their market realization. These chains include numerous providers of various services, financial institutions, travel and information infrastructures, i.e. everything that has direct or indirect effects on the activities carried out by the other members of the cluster. The development of industry leads to an accelerated economic development, whereas the improvement of its innovativeness stimulates change in the economic and market structures. The development of a greater number of production enterprises performing similar activities in geographically close locations gradually leads to changes in the local environment. The environment begins to tune itself in to the business enterprise by attracting customers, laborers, potential partners and other subjects who want to achieve financial benefits. The presence of strong local competitiveness is a powerful stimulus for the creation and preservation of competitive advantage. Industries performing the same activity, located in one region, have more chances to be internationally competitive (Italian textile industry, Swiss pharmaceutical industry) than the powerful industries that independently act in the region. Deformity in competitiveness, as a rule, means that protected enterprises ask for the subvention of the country, which often results in a decline in competitiveness within the international framework. The industrial cluster of a region is believed to have comparative advantages by the mere fact that the productivity and size of the cluster are relatively large in comparison to other regions (Porter, 2008, 184). An approach to new, innovative technologies is made easier through the creation of clusters, which increases the importance and role of a cluster from the aspect of the imperative of the improvement of innovation.

The best-known innovative milieus in the world are Silicon Valley and Boston-Massachusetts (USA), Darmstadt and Munich (Germany), Cambridge (Great Britain), Grenoble and Sophia-Antipolis (France), Pisa and Piacenza (Italy). There, the concentration of innovative institutions and enterprises was accomplished, which led to "creation of collective process of learning where the development of knowledge and skills within one enterprise or research institution spread over other companies"
(Puljiz 2011, 75). This is due to the fact that, in a community characterized by strong social and business ties, the process of the creation of new knowledge is more pronounced. New knowledge is cumulatively embodied in the innovations of products and processes that contribute to the creation of long-lasting competitive advantages at the regional level (Armstrong \& Taylor, 2000).

The development of a certain form of a spatial innovation system has become one of the priorities in many countries; this is logical, bearing in mind the fact that workplaces in them stand out for the level of productiveness and the amount of earnings. However, the problem is in the fact that there is a great discrepancy between the results of scientific research and specific advice on particular interventions of a country. A number of analysts reasonably notice that future research has to perceive the nature of regional preconditions necessary for clusters to make a success (Armstrong, 1995).

The previously listed concepts of regional growth are characterised by multidisciplinary approach in the real sense of the word. They count on numerous innovations in the domain of economy, administration etc. A great number of factors which interest research belong to the category of size which not always easy to measure, such as mutual trust of participants, quality of institutions, entrepreneur capabilities and the similar. Spatial innovation systems especially take care of development and significance of institution, which include research and development centres of enterprises, universities, public sector, and often even policies of development of science and technology at the national level (Puljiz, 2009; 2011).

The previously analyzed attitudes confirm the $\mathrm{H} 0$ hypothesis, according to which the contemporary theories of regional development (the theory of endogenic growth, the new economic geography, teaching on spatial innovation systems) accentuate the significance of the non-material factors of regional growth. 


\section{THE NONLINEAR CHARACTER OF THE RELATIONSHIPS BETWEEN THE ECONOMIC GROWTH OF A COUNTRY AND ECONOMIC (IN)EQUALITIES}

In the 1960s, F. Pérroux (1955, 307-340) explained the expression of the non-linear relationship between the economic growth of a country and regional inequalities by using the logic of the existence of the poles of growth. He related the process of the convergence of the developed by economically lessdeveloped regions to the expression of the effects of the acceleration and expansion of development. It should be noted that at that time F. Pérroux relied on J. A. Schumpeter's thesis $(1961,65)$ that entrepreneurs' innovative behavior is the key to economic growth. The accelerated development of the poles of development is called polarisation, whereas the process of convergence developed by the economically less-developed is denoted as the effect of the expansion of development. Polarisation can be performed in two basic ways. The first is the mechanism of the disappearance of enterprises located in less-developed areas as a consequence of the technological and organizational superiority of enterprises from the developed areas. The second process implies the migrations of educated people from less-developed to economically more prosperous areas. The inevitable result of this process is a decrease in the human resources that are available in less-developed regions, for which reason it becomes the basis of their long-term regression. This phenomenon leads to a slowdown in economic growth in certain regions. On the other hand, the effects of the expansion of development appear when the development of the center "draws" the economic growth of the periphery as well, e.g. due to increased demand for the products of the enterprises in the periphery (Clunies-Ross, Forsyth \& Hug, 2009).

A diametrically opposite attitude towards the relationships of the economic growth of a country and regional inequalities can be found with neoclassical theoreticians. Their most significant message is related to the tendency of a decrease in the developmental inequalities of a region in accordance with the progress made in the economic growth of a country. According to neoclassical economists, the developmental convergence of a region is a result of the expression of a decreased yield of physical capital and labor.

Neoclassical theory suggests that a location does not play an important role in generating economic growth. Namely, according to neoclassical economists, it is unimportant for entrepreneurs whether a central or a peripheral region is in question, since they make decisions on investments in accordance with the expected yield. The claim that economically less developed regions have a more pronounced growth rate per capita in comparison to more-developed regions, as a result of a relatively less expressed tendency of decreasing the yields of production factors in economically less-developed environments, regardless to other elements, is known as the hypothesis of absolute convergence in the theory and policy of economic growth. In the 1970s and the 1980s, this hypothesis was subjected to numerous tests and was subject to frequent rejections in economic research (Barro \& Sala-i-Martin, 2004, 5657). Assuming that, in a structural sense, regions are incomparably more homogenous units than certain countries are, it can be concluded that the thesis of absolute convergence is more applicable in an analysis of regional inequalities in comparison to the research in economic imbalance in certain countries.

Bearing in mind the starting premises of neoclassical observations, it is logical to assume the existence of the pronounced interregional mobility of productive factors. In that context, the directions of the movement of the factors of capital and labor are determined by the expected yield of such factors. Capital owners will direct their investments towards the regions where the highest yield will be achieved, whereas labor will move on to the regions where earnings are the greatest. According to the logic of neoclassical theory, a further sequence of events is that the regions with the high coefficients of capital equipment will be characterized by a low yield of capital and high earnings. Capital and labor will move on in different directions. The regions with a lower coefficient of the capital equipment of labor will be potentially 
attractive to entrepreneurs for capital investment due to a high yield, whereas the regions characterized by relatively high earnings will be attractive to workers from other regions. In the long run, the equalization of the relationships between capital and labor (the coefficient of the capital equipment of labor) in certain regions has to take place, i.e. the convergence of a region by the criterion of realized production per employee. However, bearing in mind the fact that numerous empirical investigations revealed increasing regional inequalities, it follows that the message of absolute convergence of regions in a longterm period is opposite to economic reality. It means that the neoclassical model of growth has not offered appropriate guidelines to the creators of the policies of regional development to overcome increasing regional divergences within specific countries.

For neoclassical economists the expression of the law of a decreasing yield of factors and perfect competition as the predominant ambience where economic subjects maximize their target functions has never been brought into question. These theoretical attitudes, projected on the phenomenon of the economic growth of a region, implicate the attitude towards the inevitability of their economic convergence in the long run. In other words, neoclassical economists think that, taking a long period into account, the elimination of regional inequalities in certain countries is the only logical outcome of the developmental processes over time.

However, regional reality in many countries was quite different from this statement by neoclassical economists. Namely, the developmental divergences of a region were often expressed. The slow economic growth of many regions, as well as the tendency of growing developmental divergences in the 1970s, meant that many factors influenced the economic growth of a region, despite great investments in an increase in physical capital. Hence the message of the endogenic theories of growth is that the regions of an observed country need not unconditionally achieve a stable rate of balance growth. Growth at the rates higher than the balanced can be sustainable. Regions need not unconditionally converge. The expression of the non-decreasing yields of factors is connected with the effects of "learning by doing", the phenomenon of "knowledge spillover", the activities of research and development, education, as a factor of an increase in human capital, etc. (Romer, 2006, 13; Cvetanović \& Despotović, 2014, 13).

The concept of learning by doing originates from K. Arrow (1971, 131-149). Individuals are better if they produce more. Besides ${ }_{\iota}$ certain producers learn from the practical experience of others. Incorporating the hypothesis of knowledge spillover into this teaching, P. M. Romer (1986) published a large number of papers in the late nineteen eighties, revived the interest of macroeconomists in key issues of economic growth of countries and regions. By P. M. Romer (1986), independently of the fact that „productive function for each individual enterprise can also have standard neoclassical form, the expression of law on decreasing returns need not appear on macro level. He considers this possible thanks to the fact that efficiency of factor of capital of particular enterprise can grow due to increased stocks of physical capital in other enterprises" (Cvetanović \& Despotović, 2014, 13). Accordingly, the growth of physical capital at macro level initiates the wave of positive external effects, which means that decreasing returns factors need not necessarily appear in economy as a whole (Mervar, 2003).

The applicability of messages of endogenous models of growth in the explication of regional divergences is established in the starting point that the processes of dissemination of knowledge are considerably geographically limited. Interpersonal interaction, connected with the level of education of the population at the local level results in the existing and attraction of new human capital. The increase of human capital leads to innovations and economic growth. The regions which are abundant with this form of capital achieve dominant position in innovativeness in comparison to the regions with relatively small scope of human capital (Puljiz, 2011). Economically less developed regions are not attractive places for educated individuals (smaller earnings, uncertain sources of financing entrepreneur attempts) are doomed for permanent economic regression. 
The endogenic models of growth explicate the developmental divergence of regions to a satisfactory degree (developed regions invest more in education, research and development, the creation of an innovation ambience). However, their message of a possible convergence is far more important, i.e. the economic convergence of developed regions by the less-developed, and the need to act towards increasing the innovation capacity of certain areas by the most diverse interventions of the regional policy.

According to P. Krugman (1990), the creator of the concept of the new economic geography, an increase or a decrease in regional inequalities is determined by the influence of centripetal and centrifugal forces. The former stimulate the concentration of the economic activities of a region, whereas the latter act in the opposite direction. When centripetal forces overpower, their outcome makes regional inequalities grow. Or vice versa - when centripetal forces overpower, regional convergences are expressed (Figure 6).

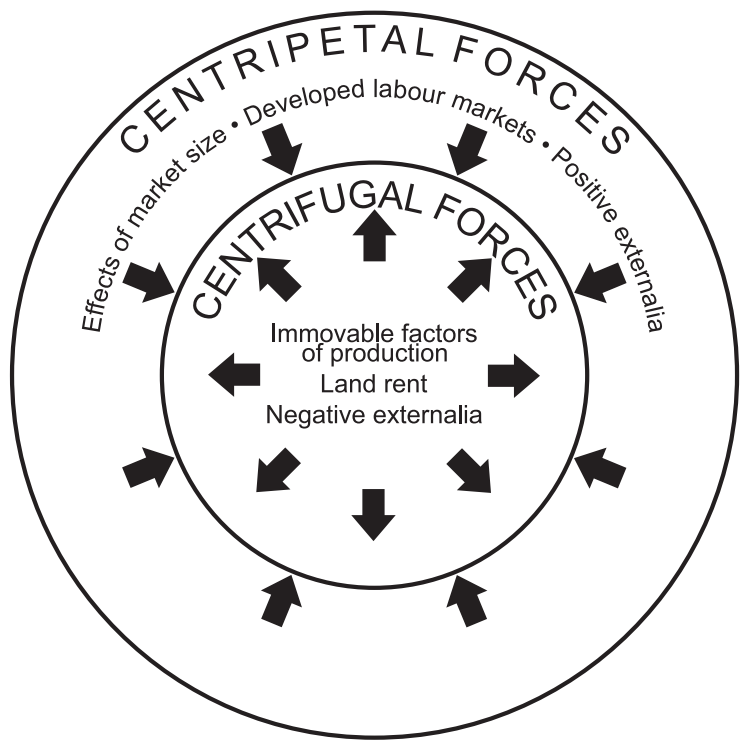

Figure 6 Centripetal and centrifugal forces in the model of the new economic geography

Source: Authors, according to: Puljiz, 2011, 71, based on: Krugman, 1990
However, the fact is that competent empirical research which would test the validity of the key messages of the new economic geography of the expression of the developmental inequalities of regions is missing. One of the reasons for this is that the model of the new economic geography is very demanding, not only in terms of the availability of the necessary data, but also in the expressed problems related to the formulation of the models of the economic growth of a region and the course of regional inequalities.

Recent approaches in the theory of regional development, marked in this paper as spatial innovation systems (innovation hubs), support the idea of increasing regional divergence in the contemporary conditions of enterprising. It is logical, bearing in mind the fact that according to their interpretation, the economic growth of a region is based on the spatial concentration of highly innovative enterprises, which are in a very close mutual contact, as well as with other parties in a specific area. For instance, thanks to their innovation superiority in certain domains, the regions such as the Silicon Valley in the USA, the Innovation Centre Antipolis in France, the Technological Park Pretoria in South Africa, the Technological Park Hsinchu in Taiwan and the Center for Software Engineering Bangalore in India have become the symbols of economic power in world relations during the last thirty years (Smith, 2010, 266).

The previously explicated attitudes confirm the H1 hypothesis, according to which contemporary attitudes in regional theory explain the phenomenon of the developmental divergence of a region to a satisfactory degree.

\section{CONCLUSION}

The interest of a regional economy in the investigation of the key factors of regional growth and the nature and character of the relationship between the economic growth of a country and regional inequalities has greatly expanded over the last decades. However, despite the intensive development 
of the regional economy in this period, it is obvious that there are no uniform researchers' attitudes related to these issues.

A critical analysis of the attitudes in the five significant theoretical approaches in the regional economy in terms of the key factors of regional growth, on the one hand, and the non-linear character of the relationship between the economic growth of a country and regional inequalities, on the other, can be considered as the contribution of this paper. Besides, the paper concludes that, according to the attitudes expressed by the representatives of certain theories in the regional economy, they agree in the opinion that the so-called non-material sources have a predominant role among the factors of regional growth, whereas the developmental divergence of a region corresponds to the economic growth of the observed country.

The defined basic and additional hypotheses were tested and confirmed through the research process. The limitation of the conducted research was in the omission of quantitative explications, which is understandable in a certain sense, since the influence of the non-material factors of regional growth, on the one hand, and the complex relationships between the economic growth of the country and the expression of regional inequalities, on the other, are very difficult to precisely define.

In our opinion, the results of the research can be useful to the creators of regional policies in small and insufficiently developed countries, such as ours, in that they should pay more attention to the nonmaterial factors of regional growth when creating a policy of regional development. Thus, further research could quantify the influence of non-material factors on regional growth and precisely determine the character of the non-linear relationship between the economic growth of a country and the expression of regional inequalities.

\section{REFERENCES}

Armstrong, H. (1995). Convergence among regions of the European Union, 1950-1990. Papers in Regional Science, 74(2), 143-152. doi: 10.1111/j.1435-5597.1995.tb00633.x

Armstrong, H., \& Taylor, J. (2000). Regional economics and policy. Oxford, UK: Wiley-Blackwell.

Arrow, K. (1971). The economic implications of learning by doing. In F. H. Hahn (Ed.), Readings in the Theory of Growth (pp. 131-149). UK: Palgrave Macmillan. doi: 10.1007/978-1349-15430-2_11

Baldwin, J. R., \& Caves, R. E. (1997). International competition and industrial performance: Allocative efficiency, productive efficiency, and turbulence. Statistics Canada Research Paper, No 108, 31 Pages.

Barro, R., \& Sala-i-Martin, X. (2004). Economic Growth. Cambridge, Massachusettes, US: MIT Press.

Behrens, K., \& Thisse, J. F. (2007). Regional economics: A new economic geography perspective. Regional Science and Urban Economics, 37(4), 457-465. doi.org/10.1016/j. regsciurbeco.2006.10.001

Capello, R., \& Perucca, G. (2015). Openness to globalization and regional growth patterns in CEE countries: from the EU accession to the economic crisis. Journal of Common Market Studies, 53(2), 218-236. doi: 10.1111/jcms.12157

Cheshire, P.C., \& Malecki, E. J. (2004). Growth, development, and innovation: A look backward and forward. In J. G. Raymond \& M. Florax (Eds.), Fifty Years of Regional Science (pp. 249-267). Berlin, Heidelberg: Springer. doi: 10.1007/978-3-662-07223-3_11

Clunies-Ross, A., Forsyth, D., \& Hug, M. (2009). Development Economics. McGraw-Hill.

Coleman, J. S. (1988). Social capital in the creation of human capital. American journal of sociology, 94, S95-S120.

Cvetanović, S., \& Despotović, D. (2014). Knowledge as the component of human capital in economic growth models. Škola biznisa, 1, 1-17. doi 10.5937/skolbiz1-5976

Cvetanović, S., Filipović, M., Nikolić, M., \& Belović, D. (2015). Endogenous growth theory and regional development policy. Spatium, 34, 10-17. doi: 10.2298/spat1534010c 
Davis, D. R., \& Weinstein, D. E. (1999). Economic geography and regional production structure: An empirical investigation. European economic review, 43(2), 379-407. doi.org/10.1016/S0014-2921(98)00063-4

Dragičević, M. (2012) Konkurentnost - Projekat za Hrvatsku. Zagreb, Croatia: Školska knjiga.

Florida, R. (2002). The economic geography of talent. Annals of the Association of American geographers, 92(4), 743-755. doi: 10.1111/1467-8306.00314

Florida, R. (2004). The Rise of the Creative Class: And how It's Transforming Work, Leisure, Community and Everyday Life. (Paperback Ed.).

Fujita, M., Krugman, P., \& Venables, A. J. (2001). The Spatial Economy: Cities, Regions, and International Trade. Massachusetts, USA: Cambridge, MIT Press Books.

Hirschman, A. O. (1988). The strategy of economic development. Boulder, CO: Westview Press.

Jakopin, E. (2012). Post-crisis reallocation of growth factors. Economic Horizons, 14(2), 79-90. doi: 10.5937/ ekonhor1202077J

Jones, C. (2004). Growth and Ideas. NBER, Working Paper 10767, Cambridge, MA.

Krugman, P. (1990). Increasing returns and economic geography. Journal of Plitical Economy, 99(3), 483-499.

Kurz, H. D., \& Salvadori, N. (2001). The aggregate neoclassical theory of distribution and the concept of a given value of capital: A reply. Structural Change and Economic Dynamics, 12(4), 479-485. doi.org/10.1016/S0954349X(01)00015-7

Kuznets, S. (1955). Economic growth and income inequality. The American economic review, 45(1), 1-28.

Lucas, R. E. (1988). On the mechanics of economic development. Journal of monetary economics, 22(1), 3-42. doi.org/10.1016/0304-3932(88)90168-7

Lundvall, B.-A. (1992). National Systems of Innovation: Toward a theory of Innovation and Interactive Learning. London, UK: Frances Pinter.

Luthans, F., Luthans, K. W., \& Luthans, B. C. (2004). Positive psychological capital: Beyond human and social capital. Business horizons, 47(1), 45-50. doi.org/10.1016/j. bushor.2003.11.007
Maskell, P. (2000) Future Challenges and Institutional Preconditions for Regional Development Policy Posed by Economic Globalisation. Possible Paths for Development: The Next 10-15 Years for the Nordic Countries in a European Perspective. In I. Karppi (Ed.), Future Challenges and Institutional Prerequisites for Regional Development Policy (pp. 27-87). Stockholm, Sweden: Nordregio Report No. 2000-1.

Mervar, A. (2003). Esej o novijim doprinosima teoriji ekonomskog rasta. Ekonomski pregled, 54(3-4), 369-392.

Molnar, D. (2013). Regionalne nejednakosti i privredni rast: Primer Srbije. Neobjavljena doktorska disertacija, Ekonomski fakultet Univerziteta u Beogradu, Beograd, Republika Srbija.

Myrdal, G. (1957). Rich Lands and Poor: The Road to World Prosperity. New York, NY: Harper.

Ottaviano, G. I., \& Thisse, J. F. (2005). New economic geography: What about the N? Environment and Planning A, 37(10), 1707-1725.

Pérroux, F. (1955). La Notion de Pole de Croissance. Économie Appliquée, 1-2.

Porter, M. (2008). O konkurenciji. Beograd, Republika Srbija: FEFA.

Puljiz, J. (2009). Čimbenici regionalnog razvoja i regionalnih nejednakosti u Republici Hrvatskoj. Neobjavljena doktorska disertacija, Ekonomski fakultet, Sveučilište u Splitu, Split, Republika Hrvatska.

Puljiz, J. (2011). Teorije regionalnog razvoja u ekonomskoj literaturi. Godišnjak TITIUS: Godišnjak za interdisciplinarna istraživanja porječja Krke, 3(3), 63-82.

Putnam, R. (2008). Kuglati sam. Novi Sad, Republika Srbija: Mediteran Publishing.

Romer, D. (2006). Advanced macroeconomics. Boston, US: McGraw-Hill/Irwin.

Romer, P. M. (1986). Increasing returns and long-run growth. The journal of political economy, 94(5), 1002-1037. doi.org/10.1086/261420

Schumpeter, J. A. (1961). The theory of economic development: An inquiry into profits, capital, credit, interest, and the business cycle. New York, NY: A Galaxy Book. 
Smith, D. (2010). Exploring innovation. London, UK: McGraw-Hill Higher Education.

Stimson, R. J., Stough, R., \& Nijkamp, P. (Eds.), (2011). Endogenous Regional Development: Perspectives, Measurement and Empirical Investigation. Cheltenham, UK: Edward Elgar Publishing.

Todaro, M. P., \& Smith, S. C. (2015). Economic Development. London, UK: Addison-Wesley.

Trivić, N., \& Petrov, V. (2014). Determination of the economic growth rates by the growth quality. Economic Horizons, 16(2), 125-135. doi: 10.5937/ekonhor1402129T
Ulrich, D. (1998). Intellectual capital - competence x commitment. MIT Sloan Management Review, 39(2), 15.

Vazquez-Barquero, A. (2002). Endogenous Development Networking, Innovation, Institutions and Cities. London, UK: Routledge.

Venables, A. J. (1996). Equilibrium locations of vertically linked industries. International economic review, 37(2), 341359. doi:10.2307/2527327

Williamson, J. G. (1965). Regional inequality and the process of national development: A description of the patterns. Economic development and cultural change, 13(4), $1-84$.

\section{Received on $14^{\text {th }}$ April 2017, after two revisions, accepted for publication on $23^{\text {rd }}$ August 2017. Published online on $25^{\text {th }}$ August 2017.}

Danijela Despotovic is an Associate Professor at the Faculty of Economics, University of Kragujevac, the Republic of Serbia. She teaches courses in Theory and analysis of economic policy and Macromanagement. She received her PhD deegre in Macroeconomics, at the Faculty of Economics, University of Kragujevac. Her main research interests include: economic policy and development, and sustainable development.

Slobodan Cvetanovic is a Professor at the Faculty of Economics, University of Nis, the Republic of Serbia. He teaches courses on Macroeconomics, Financing the Capital Development of the Economy, Macroeconomics and Macroeconomic Management. He obtained his PhD deegre in macroeconomics, at the Faculty of Economics, University of Belgrade. Narrower field: macroeconomics, economic development, innovation, sustainable development. 


\title{
TEORIJSKA EKSPLIKACIJA FAKTORA REGIONALNOG RASTA I EKONOMSKE KONVERGENCIJE (DIVERGENCIJE) REGIONA
}

\author{
Danijela Despotović ${ }^{* 1}$ i Slobodan Cvetanović \\ 'Ekonomski fakultet Univerziteta u Kragujevcu; ' ${ }^{2}$ Konomski fakultet Univerziteta u Nišu
}

\begin{abstract}
Tokom nekoliko poslednjih decenija postoji kontinuirano interesovanje ekonomista za istraživanje ključnih faktora ekonomskog rasta i razvojne konvergencije (divergencije) regiona. Međutim, i pored brojnih teorijskih i empirijskih istraživanja pomenutih kategorija, evidentno je da još uvek ne postoji opšteprihvaćeno objašnjenje ključnih faktora regionalnog rasta. Istovetan zaključak je i kada se ima u vidu postojanje veze između privrednog rasta zemlje i tendencije ka uvećanju, odnosno, smanjenju regionalnih nejednakosti. U radu je data teorijska eksplikacija ključnih faktora regionalnog rasta i fenomena razvojne konvergencije (divergencije) regiona, pet reprezentativnih pravaca u regionalnoj ekonomiji (klasičnog, neoklasičnog, endogenog, nove ekonomske geografije i prostornih inovacionih sistema). Aktuelna privredna stvarnost na globalnom planu, koja govori o sve većoj regionalnoj nejednakosti, potvrđuje ispravnost teorijskih konsidercija predstavnika savremenih teorijskih pravaca $\mathrm{u}$ vezi sa analiziranim pitanjima.
\end{abstract}

Ključne reči: regionalna ekonomija, privredni rast regiona, konvergencija (divergencija) regionalnog razvoja, savremene teorije

JEL Classification: 011

\section{UVOD}

Istraživanja ključnih faktora privrednog rasta i razvoja regiona prisutna su u ekonomskoj nauci počev od sredine XX-og veka (Cvetanović, Filipović, Nikolić \& Belović, 2015). Premda u vezi sa ovim pitanjem nema potrebnog jedinstva stavova teoretičara najznačajnijih pravaca $\mathrm{u}$ regionalnoj ekonomiji, $\mathrm{u}$ ovom radu

* Korespondencija: D. Despotović, Ekonomski fakultet Univerziteta u Kragujevcu, Đ. Pucara 3, 34000 Kragujevac, Republika Srbija; e-mail: ddespotovic@kg.ac.rs usvojen je pristup $u$ njihovom razvrstavanju na klasične, neoklasične, teoretičare endogenih objašnjenja privrednog rasta, autore nove ekonomske geografije i pristalice $\mathrm{zv}$. prostornih inovacionih sistema (Puljiz, 2009). Pritom, poslednja tri teorijska pravca pripadaju grupi tzv. savremenih teorija regionalnog razvoja. Analizom stavova teoretičara koji reprezentuju pomenute teorijske pravce $u$ regionalnoj ekonomiji zapaža se promena težišta $u$ vrednovanju najznačajnijih faktora regionalnog rasta, od proizvedenih i prirodnih faktora ka faktorima 
znanja, inovacija i umreženosti (Trivić \& Petrov, 2014). Teorijske konsideracije o konvergenciji ili divergenciji bruto domaćeg proizvoda po stanovniku među regionima tokom vremena razlikuju se, takođe, u zavisnosti od pripadnosti pojedinih istraživača prethodno pomenutim pravcima $\mathrm{u}$ regionalnoj ekonomiji.

Predmet istraživanja $\mathrm{u}$ radu predstavlja teorijska eksplikacija ključnih faktora regionalnog rasta i razvoja, kao i relacija između privrednog rasta zemlje i regionalnih nejednakosti u ekonomskoj nauci.

Cilj je da se istraže najznačajniji faktori privrednog rasta i razvoja regiona i relacije između privrednog rasta zemlje i regionalnih nejednakosti, u značajnijim teorijskim pravcima $u$ regionalnoj ekonomiji, počev od njenog nastanka tokom pedesetih godina $\mathrm{XX-og}$ veka.

Shodno opredeljenom predmetu i postavljenom cilju istraživanja, osnovna hipoteza rada je:

H0: Savremene teorije regionalnog razvoja akcentiraju značaj nematerijalnih faktora regionalnog rasta.

Pored osnovne, definisana je i sledeća pomoćna hipoteza:

H1: Savremene teorije regionalnog razvoja preferiraju stav o postojanju rastućih razvojnih divergencija regiona.

U metodološkom smislu, $u$ radu su izbegnute eksplikacije složenih kvantitativnih predstavljanja najznačajnijih faktora ekonomskog rasta, sagledavanog na nacionalnom i regionalnom nivou, kao i odnosa između privrednog rasta zemalja i regionalnih nejednakosti, koja dominiraju $u$ istraživanjima ovih fenomena u relevantnoj ekonomskoj literaturi. Učinjen je pokušaj da se $u$ svetlu divergentnih stavova pojedinih teorijskih pravaca u regionalnoj ekonomiji povodom ova dva pitanja, deskriptivnom analizom i grafičkim eksplikacijama objasne ključni faktori privrednog rasta regiona, kao i odnos između privrednog rasta zemlje i regionalnih nejednakosti.

Strukturu rada, pored uvoda, zaključka i spiska korišćene literature čine tri sekcije: Regionalni razvoj i regionalne nejednakosti, $\mathrm{O}$ faktorima regionalnog rasta u ekonomskoj teoriji, i Nelinearni karakter odnosa između privrednog rasta zemlje i regionalnih (ne)jednakosti. U prvoj sekciji učinjen je opšti osvrt na faktore regionalnog razvoja i stavove najznačajnijih predstavnika pojedinih pravaca u ekonomskoj teoriji povodom relacija između privrednog rasta zemlje i tendencija u kretanju regionalnih (ne)jednakosti. Ukazuje se da na čisto konceptualnom planu, regionalna politika ima za cilj da optimizira dva $u$ osnovi kontradiktorna cilja - ubrzanje privrednog rasta zemlje, s jedne, i smanjenje razvojnih nejednakosti njenih prostornih celina (regiona), $\mathrm{s}$ druge strane. $\mathrm{U}$ drugoj su prezentovana viđenja, pristalica značajnijih teorijskih pravaca na koje se naslanja savremena regionalna ekonomija (klasični pravac, neoklasična ekonomska škola, kejnsijanska ekonomska misao, teorija privrednog razvoja, endogena teorije rasta, tzv. nova ekonomska geografija, pristup prostornih inovacionih sistema) povodom ključnih faktora privrednog rasta regiona, dok se u trećoj sekciji daje kritička analiza stavova ovih teorijskih pravaca po pitanju međusobnog odnosa između privrednog rasta zemlje i ispoljavanja regionalnih (ne)jednakosti.

\section{REGIONALNI RAZVOJ I REGIONALNE NEJEDNAKOSTI}

Proučavanju faktora regionalnog rasta i ekonomske konvergencije (divergencije) regiona moguće je prići iz različitih uglova (Slika 1). R. Capello i G. Perucca (2015) smatraju da su postulati teorije lokacije i teorije regionalnog rasta i razvoja od presudnog značaja u postupku vrednovanja faktora regionalnog rasta. U zavisnosti od prihvaćene koncepcije prostora, razlikuju se ključni pokretači regionalnog razvoja. Na produktivnost faktora i veličinu dohodovnih multiplikatora dominantan uticaj imaju međuregionlna alokativna efikasnost i unutarregionalni mulitiplikativni mehanizmi (Stimson, Stough \& Nijkamp, 2011, 10).

Tokom šeste i sedme decenije XX-og veka u ekonomski najnaprednijim zemljama sveta, regionalna ekonomija je bila zaokupljena sagledavanjem značaja specijalizacije proizvodnje i rastuće uloge države 


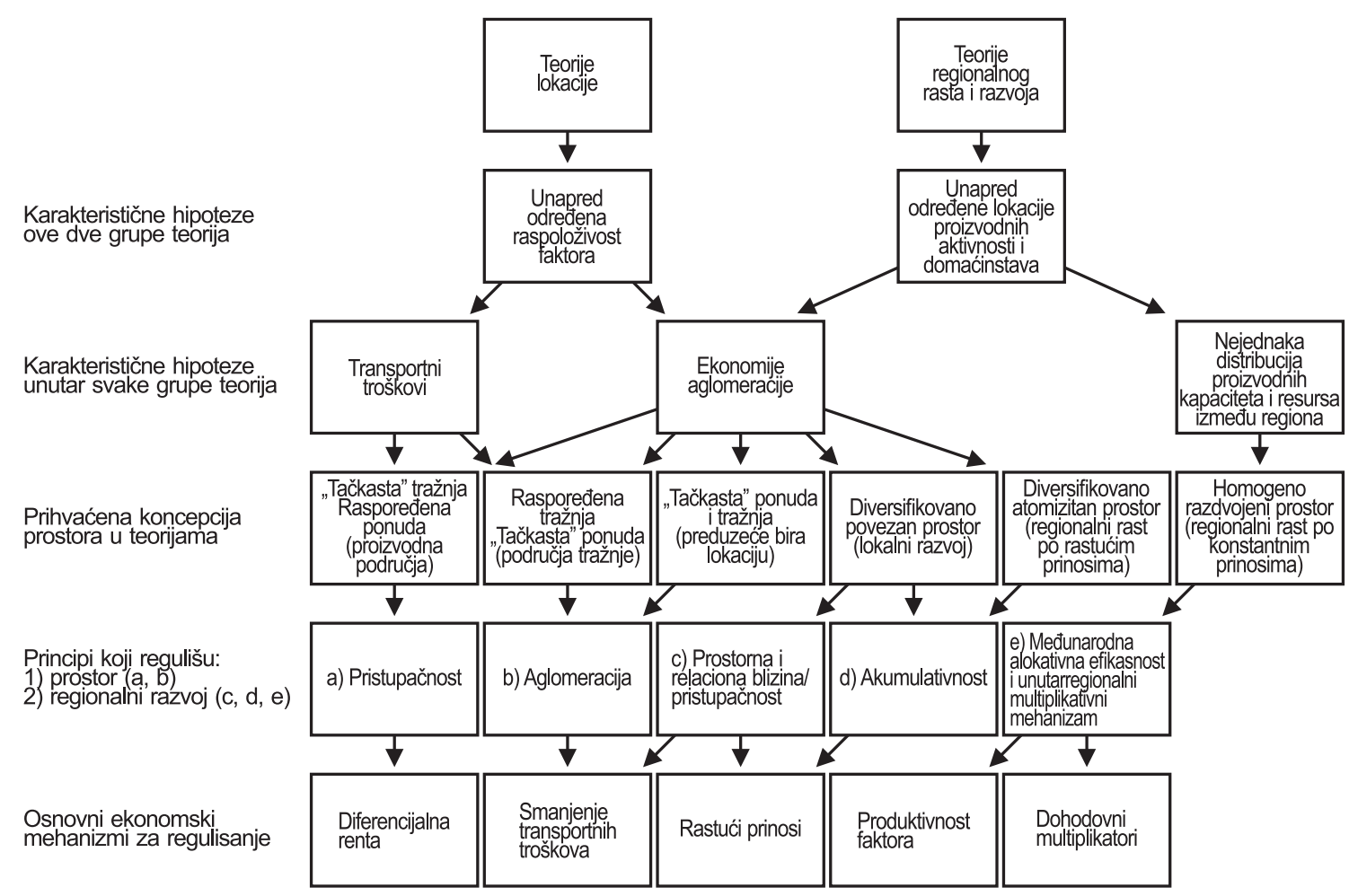

Slika 1 Razvoj regionalne ekonomije

Izvor: Stimson, Stough \& Nijkamp, 2011, 10

$\mathrm{u}$ pokretanju regionalnog rasta. U osamdesetim i devedesetim godinama XX-og veka, pod uticajem globalizacije i snažnog tehnološkog razvoja došlo je do ekonomskog uzleta pojedinih regiona koji su istovremeno počeli da dominiraju svetskom privredom.

O relacijama između veličine regionalnih nejednakosti i dostignutog nivoa razvijenosti zemlje među prvima je pisao J. G. Williamson (1965, 3-45). On je rezultate svojih istraživanja prezentirao u vidu zakonitosti po kojoj rast bruto domaćeg proizvoda po stanovniku najpre uslovljava uvećanje, a nakon dostizanja određenog nivoa bruto domaćeg proizvoda po stanovniku dovodi do smanjenja regionalnih nejednakosti (Slika 2).

Eksplicirana ideja J. G. Williamson-a o nelinearnoj vezi između dostignutog nivoa bruto domaćeg proizvoda po stanovniku u posmatranoj zemlji i regionalnih nejednakosti $\mathrm{u}$ obliku obrnutog slova $\mathrm{U}$ u potpunosti je preuzeta od S. Kuznets-a (1955), koji je na temelju obimnih empirijskih istraživanja došao do zaključka da u početnim fazama privrednog razvoja postoji tendencija uvećanja nejednakosti

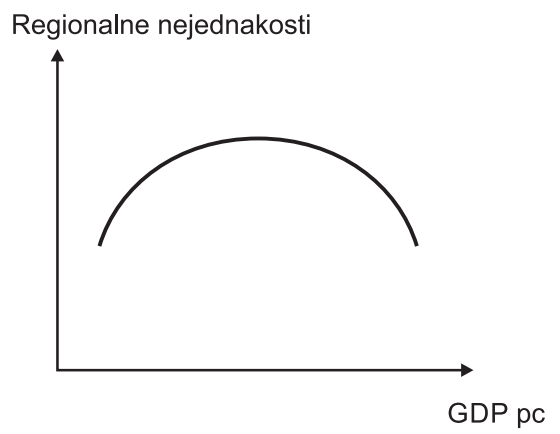

Slika 2 J. G. Williamson-ova obrnuta U-kriva Izvor: Davis \& Weinstein, 1999, 5 
u raspodeli bruto domaćeg proizvoda koja opada na višim nivoima privredne razvijenosti zemlje. Međutim, nezavisno od stava u vezi sa originalnošću iznesene ideje, činjenica je da je J. G. Williamson skrenuo pažnju regionalnih ekonomista na nelinearnu prirodu odnosa između nivoa regionalnih nejednakosti $u$ okviru pojedinih zemalja i veličine bruto domaćeg proizvoda po stanovniku, što se ispostavilo kao izuzetno značajno stanovište prilikom sagledavanja regionalnih aspekata privrednog rasta i razvoja tokom poslednjih pedesetak godina. $\mathrm{Na}$ čisto konceptualnom planu, regionalna politika ima za cilj da optimizira dva u osnovi kontradiktorna cilja - ubrzanje privrednog rasta zemlje, s jedne, i smanjenje razvojnih nejednakosti njenih prostornih celina (regiona), s druge strane. Stvaranje privredno razvijenih regiona, sposobnih da se integrišu u globalne ekonomske tokove, osnovni je cilj upravljanja regionalnim razvojem (Maskell, 2000).

\section{O FAKTORIMA REGIONALNOG RASTA U EKONOMSKOJ TEORIJI}

Najčešće se u ekonomskoj teoriji pod klasičnom literaturom o privrednom razvoju podrazumevaju istraživanja koja su realizovana polovinom XX-og veka, u kojima je dominiralo sagledavanje značajnijih faktora privrednog rasta i razvoja regiona i fenomena regionalnih nejednakosti (Puljiz, 2011). Imajući u vidu konceptualne osnove teorija regionalnog razvoja, ovde se prvenstveno svrstavaju radovi F. Pérroux-a (1955), G. Myrdal-a (1957) i A. O. Hirschman-a (1988).

Po mišljenju klasičnih teoretičara regionalnog razvoja tri ključna faktora privrednog rasta regiona su: fizički kapital, prirodni kapital i ljudski kapital. Povodom drugog pitanja koje se razmatra $u$ radu, decidno zastupaju stav o ispoljavanju regionalnih nejednakosti.

Najpoznatije učenje esencijalnih pitanja regionalnog razvoja svakako je teorija polova rasta F. Pérroux-a, koja je postala gotovo sinonim za teoriju regionalnog razvoja. F. Pérroux, kao i ostali klasični teoretičari koji su se bavili tematikom regionalnog rasta, polazi od činjenice da se razvoj ne odvija ravnomerno i zaključuje da se razvoj koncentriše u pojedinim žarišnim tačkama u prostoru, odnosno, drugim rečima, on se polarizuje. F. Pérroux svoju analizu smešta u realni, polarizovani prostor, sa znatnim razlikama u pogodnostima lokacija za privlačenje investicija i ubrzanje razvoja. F. Pérroux razlikuje talas polarizacije, u kome se oformljuju takvi polovi rasta, od talasa disperzije kada se razvojni podsticaji polova rasta prenose na njihovu zonu uticaja. Intenzitet talasa disperzije predstavlja i kriterijum za merenje jačine samog pola razvoja (Pérroux, 1955).

Jedno od najpoznatijih objašnjenja problematike polova rasta $\mathrm{u}$ regionalnoj ekonomiji je hipoteza kružne i kumulativne uzročnosti G. Myrdal-a (1957). Prema ovom autoru, faktori privrednog rasta regiona (pre svega ljudski kapital) odlaze $u$ regione koji se brže razvijaju i ostvaruju rast prinosa, a udaljavaju se od regiona sa sporijim rastom. Navedeni proces često se primećuje u zemljama u razvoju.

A. O. Hirschman (1988) u svojim istraživanjima posebno ukazuje na sledeća dva uzroka zaostajanja ekonomski manje razvijenih regiona $u$ odnosu na napredne regione. Prvi se odnosi na pojavu istiskivanja preduzeća iz manje razvijenih područja pred konkurencijom preduzeća iz ekonomski naprednih regiona, a drugi na migraciju školovanih ljudi iz manje razvijenih regiona $\mathrm{u}$ ekonomski naprednije sredine.

Neoklasičari su mišljenja da je rast vrednosti proizvodnje na nacionalnom i regionalnom nivou rezultat povećanja fizičkog kapitala, uvećanja radne snage i usavršavanja tehnologije (Barro \& Sala-iMartin, 2004). Pretpostavljaju homogenost prostora $u$ kojem svaka tačka ima jednake lokacione pogodnosti. Zemlje, odnosno regioni koji manje investiraju u fizički kapital, koji imaju nižu stopu rasta stanovništva i koji relativno sporije usavršavaju tehnologiju, per se imaju niže stope privrednog rasta $u$ odnosu na zemlje, tj. regione koji relativno više investiraju u rast fizičkog kapitala, imaju izraženiju stopu rasta stanovništva $\mathrm{i}$ intenzivnije usavršavaju tehnologiju shvaćenu $\mathrm{u}$ najširem smislu te reči (Slika 3).

Neoklasična objašnjenja privrednog rasta regiona 
polaze od pretpostavki o ispoljavanju ekonomije obima, ponašanju privrednih subjekata u skladu sa cenama utvrđenim na savršeno konkurentnim tržištima, odsustvu eksternalija, postojanju tehnoloških promena egzogenog karaktera. Ona, u potpunosti, zanemaruju značaj institucionalnih faktora i mogućeg stimulativnog uticaja regionalne politike na privredni rast (Kurz \& Salvadori, 2001). Privredni rast zemalja, odnosno, regiona, shodno logici neoklasičnih ekonomista, u kratkom i srednjem roku temelji se na korišćenju veće količine fizičkog kapitala i rada. $\mathrm{U}$ dugom roku, privredni rast regiona moguć je isključivo zahvaljujući tehnološkom napretku.

Teoretičari endogenog razvoja smatraju da je intenzitet ekonomskog rasta zemalja i regiona značajno determinisan prirodom i kvalitetom osnovnih privrednosistemskih odrednica zemlje i politike ekonomskog razvoja konkretnog regiona (Todaro \& Smit, 2015).

Brojne verzije endogenih objašnjenja privrednog rasta ukazuju na značaj postojanja odgovarajućih institucionalnih aranžmana (Cvetanović et al, 2015). Neki od njih tvrde da "lokacija industrije može biti od presudnog značaja za regionalni razvoj, i da su sinergetski efekti lokacija važni za tehnološke i druge uticaje prelivanja i inovacija" (Dragičević, 2012, 20). Postoji konsenzus $u$ regionalnoj ekonomiji da endogena teorija rasta predstavlja njihov najvažniji konceptualni okvir (Vazquez-Barquero, 2002). Globalna ekonomska kriza, dodatno je potencirala takvu ocenu (Jakopin, 2012).

Endogena teorija rasta odbacuje neoklasično viđenje tri osnovna faktora privrednog rasta regiona. Po njihovom mišljenju, pored faktora fizičkog kapitala, rada i tehnologije, od esencijalne važnosti za dugoročno održivi regionalni rast (ORR) su proizvodni $(\mathrm{P})$, humani $(\mathrm{H})$, socijalni $(\mathrm{S})$, kreativni $(\mathrm{K})$ i ekološki (E) kapital (K) (Slika 4).

Uvećanjem pet odnosnih oblika kapitala u manje razvijenim regionima kreira se potencijal za razvoj i apsorbovanje podsticaja i razvojnih impulsa koji dolaze iz ekonomski razvijenijih regiona. Manje razvijeni regioni, pod pretpostavkom da ostanu uskraćeni za bilo koji od navedenih oblika kapitala, verovatno će ostati nerazvijeni, čak i u situaciji kada im budu dodeljena određena sredstva za razvoj.

Značaj proizvodnog kapitala potiče iz neoklasičnih teorija rasta po kojima proizvodnju dominantno determinišu tradicionalni faktori proizvodnje, rad i fizički kapital. Fizički kapital se u literaturi o regionalnom razvoju najčešce sreće pod nazivom kapitalna dobra, čija je ključna karakteristika da su ona output u prethodnom, a input $\mathrm{u}$ narednom procesu proizvodnje. Najvažnije komponente fizičkog kapitala su proizvodna oprema (mašine, alati i dr.). Značaj fizičkog kapitala u pokretanju privrednog rasta regiona određuje njegova struktura, inenzitet

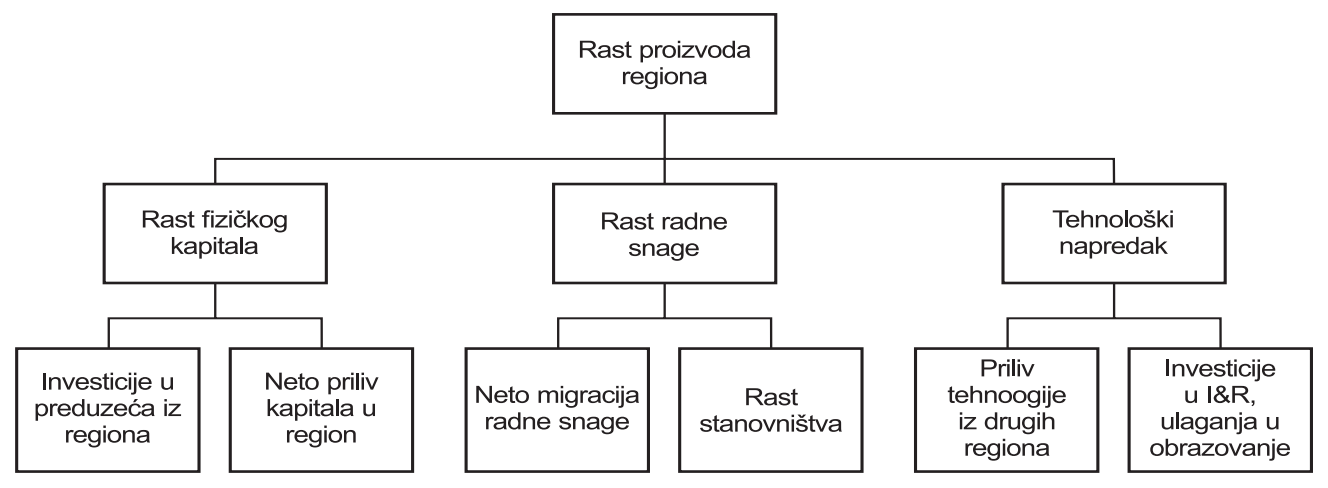

Slika 3 Faktori privrednog rasta regiona u interpretaciji neoklasičnih ekonomista 


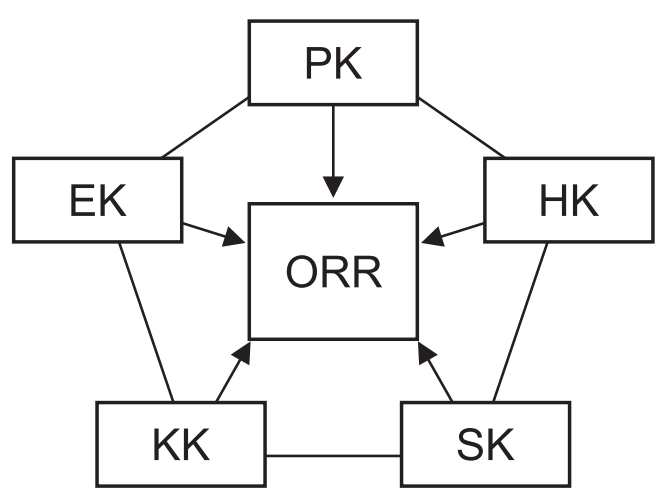

Slika 4 Faktori privrednog rasta regiona u interpretaciji pristalica endogene teorije

Izvor: Stimson, Stough \& Nijkamp, 2011, 10

uvećanja i efikasnost korišćenja. Poseban segment fizičkog kapitala predstavlja infrastruktura.

Humani kapital se ubraja u centralne elemente savremene teorije privrednog rasta. Najznačajnije komponte humanog kapitala su obrazovni nivo i zdravstveni status populacije, motivisanost ljudi za rad i razvoj (Ulrich, 1998; F. Luthans, K. W. Luthans \& B. C. Luthans, 2004). Uvećanje humanog kapitala donosi rast bruto domaćeg proizvoda zemalja i regiona (Lucas, 1988). Važnost ulaganja u humani kapital „prepoznat je u savremenim privredama, posebno u uslovima sveobuhvatne primene rezultata nauke $u$ proizvodnom procesu, intenzivnog razvoja novih tehnologija i kontinuiranog i dinamičnog usavršavanja formi i metoda upravljanja kao i organizacije proizvodnje. Sigurno je da su u modernim društvima, obrazovanje, veštine i znanje ključne komponente produktivnosti pojedinaca i privrede u celini“" (Cvetanović \& Despotović, 2014, 2). Znanje, kao komponenta humanog kapitala, pokazuje mogućnosti da se uvećava, i da se koristi bez ikakvih ograničenja. Stoga na značaju dobijaju kategorije poput produktivnosti sektora istraživanja i razvoja, kognitivnog kapaciteta, primena i difuzija znanja (Lundvall, 1992; Jones, 2004).

Socijalni (društveni) kapital je kapital saradnje, međusobnog delovanja, uzajamnog poverenja i uzajamne pomoći ljudi u ekonomskim procesima. Ne može biti u privatnom vlasništvu i ima atribute javnog dobra. Dobrim delom predstavlja rezultat pravnog, političkog i institucionalnog ambijenta u kome ekonomski akteri funkcionišu, odnosno obavljaju svoje funkcije i realizuju ciljeve. Reč je o kapitalu trajnih i u određenom stepenu institucionalizovanih odnosa između pojedinaca i organizacija, koji podstiču kreiranje ekonomskih vrednosti. U literaturi se sreću stavovi da jedino sudelovanje ljudi $\mathrm{u}$ formalnim organizacijama vodi stvaranju socijalnog kapitala, ali nisu sporadične ni dijametralno suprotne refleksije u kojima najmanja participacija ljudi u društvenim pokretima predstavlja komponentu socijalnog kapitala. J. S. Coleman (1988, 95-120), kao jedan od tvoraca koncepta socijalnog kapitala, određuje ovu kategoriju preko njegovih funkcija. Mišljenja je da socijalni kapital omogućuje individualne uspehe, budući da pojedinci iz njega izvlače koristi. Predstavlja poseban oblik javnog dobra koje je potencijalno na raspolaganju svima uključenim $\mathrm{u}$ sistem društvenih veza i odnosa. Po R. Putnam-u (2008, 20), socijalni kapital čine atributi organizacije društva poput poverenja, normi, a takođe i najraznovrsnijih mreža koji mogu da unaprede društvenu efikasnost putem koordinisane akcije.

Kreativni kapital ima fundamentalni značaj za ekonomsku dinamiku regiona (Florida, 2002; 2004). R. Florida-ina (2004) identifikacija kreativne klase među „ljudima koji dodaju ekonomsku vrednost putem svoje kreativnosti" ide dalje od pristupa zasnovanih na tradicionalnim pokazateljima ljudskog kapitala kao faktora privrednog rasta. R. Florida (2002) razrađuje teorijski model po kome prisustvo kreativne klase na bilo kom mestu dovodi do unapređenja lokalne kreativnosti, koja se ogleda u rastućoj inovativnosti i afirmaciji tehnološki intenzivnih sektora proizvodnje. Tvrdi da je kreativnost rezultat društvene interakcije, autentičnosti i identiteta, koji zajedno generišu moć prostora i posledično ekonomsku dinamiku na regionalnom nivou. Ideja prema kojoj interakcija između pojedinaca vodi ka pozitivnim efektima rasta jeste, naravno, u saglasnosti sa širom literaturom o učenju i prelivanju znanja na regionalnim tržištima rada. 
Ekološki kapital čine uslovi pogodni za život i rad u nekom regionu. Ekološki čista sredina, postojanje različitih sadržaja za rekreaciju, sport, kulturu, obrazovanje i sl, značajno povećavaju inovativni potencijal regiona, a time utiču na rast kapaciteta regiona za održivi rast.

Objašnjenje ključnih faktora privrednog rasta regiona endogenih teoretičara predstavlja značajan kvalitativni pomak $\mathrm{u}$ odnosu na dominantne stavove $\mathrm{u}$ regionalnoj ekonomiji. Endogena teorija regionalnog razvoja „,beleži trostruku promenu paradigme kada je u pitanju jačanje endogenih sposobnosti regionalnog rasta: od razvojnih faktora ka inovativnim faktorima, od 'tvrdih' ka 'mekim' faktorima koji su neopipljivi - lokalna sinergija među akterima, pozitivan način upravljanja, visok nivo humanog kapitala i imovine zasnovane na znanju - i od funkcionalnog ka kognitivnom pristupu" (Molnar, 2013, 49).

Pomak u objašnjenju ključnih faktora privrednog rasta regiona i, posebno ispoljavanja razvojnih neravnoteža, predstavljaju modeli nove ekonomske geografije. Oni su počeli intenzivno da se razvijaju nakon objavljivanja rada R. Krugman-a (1990, 483-499). Tokom poslednje decenije XX-og veka publikovan je veći broj radova iz ove oblasti (Venables, 1996; Fujita, Krugman \& Venables, 2001). U godinama s kraja XX-og i početka XXI-og veka, literaturu o novoj ekonomskoj geografiji posebno su obogatili: J. Baldwin i R. E. Caves (1997), G. I. Ottaviano i J. F. Thisse (2005), i K. Behrens i J. F. Thisse (2007). Prema pristupu nove ekonomske geografije, osnovni faktori privrednog rasta regiona su transportni troškovi, eksternalije, prinosi na uložena sredstva, iz jednostavnog razloga što se pojedina preduzeća na osnovu njih opredeljuju za konkretnu teritorijalnu lokaciju.

U godinama s kraja XX-og veka došlo je do afirmacije većeg broja različitih pristupa regionalnom razvoju koji u inovacijama vide ključni pokretač privrednog rasta regiona (Puljiz, 2011). U literaturi se ovi koncepti sreću pod nazivima: industrijski klasteri, inovativni miljei, samoučeći regioni.

Njihova teritorijalna obuhvatnost je različita, i kreće se od relativno malih (industrijski klasteri), do većih teritorija (samoučeći regioni). Neretko se pomenuti koncepti objedinjeno nazivaju prostorni inovacioni sistemi (Slika 5).

Prostorni inovacioni sistemi se sastoje od većeg broja međusobno povezanih firmi $u$ pojedinim proizvodnim sektorima, uključujući dobavljače i pružaoce mnogobrojnih usluga, kao i niz pratećih institucija poput univerziteta, instituta, laboratorija itd.

$\mathrm{U}$ literaturi se najviše pisalo o industrijskim klasterima kao obliku prostornih inovacionih sistema i sve važnijem pokretaču regionalne konkurentnosti. Klasteri označavaju svojevrsni princip umrežavanja industrije, javnih i privatnih institucija i industrijskog sektora. Oni mogu doprineti poboljšanju industrijske proizvodnje povezivanjem učesnika proizvodnog lanca nekog sektora proizvodnje. Rečju, predstavljaju svojevrsnu platformu za saradnju različitih subjekata, s ciljem unapređenja konkurentnosti zahvaljujući funkcionalnoj povezanosti i mogućnosti deljenja znanja i iskustva, radi efikasne realizacije novih poslovnih poduhvata i promocije proizvedenih dobara na nacionalnim i međunarodnim tržištima. Umrežavanjem zainteresovanih aktera na realizaciji različitih poslovnih poduhvata može se doprineti jačanju konkurentnosti poslovnih subjekata, unapređenju regionalne konkurentnosti, kao i ravnomernijem regionalnom razvoju.

Industrijski klasteri su geografske koncentracije proizvodnih firmi, formiranih u cilju smanjenja troškova, korišćenjem zajedničkih kanala nabavke i distribucije, marketing strategije, itd. Motivi za poslovno udruživanje većeg broja proizvodnih firmi na određenoj teritoriji su brojni. To mogu biti: zajednički nastup na tržištima na kojima nije velika verovatnoća da se firme mogu probiti samostalno, zajedničko korišćenje visoko specijalizovanih usluga, stručne radne snage, opreme koja se koristi povremeno itd. Klaster jedne industrijske grane odlikuje se čitavim lancima funkcionalno povezanih aktivnosti, pri čemu svaka aktivnost znači dodatnu vrednost, počev od dobavljača do finalnog proizvoda i njihove tržišne realizacije. U ovim lancima učestvuju mnogobrojni davaoci najrazličitijih usluga, finansijske institucije, putna i informatička infrastruktura, 
odnosno, sve što neposredno ili posredno deluje na aktivnosti drugih članica klastera. Razvoj industrije vodi ubrzanom privrednom razvoju, dok unapređenje njene inovativnosti stumuliše promenu privredne i tržišne strukture. Razvoj više proizvodnih preduzeća sa srodnim aktivnostima na geografski bliskim lokacijama, dovodi postepeno do promena lokalnog okruženja. Okruženje počinje da se prilagođava poslovanju preduzeća privlačenjem kupaca, radnika, potencijalnih partnera i drugih subjekata koji žele da ostvare finansijske koristi. Prisustvo snažne lokalne konkurencije predstavlja snažan stimulans za stvaranje i očuvanje konkurentske prednosti. Industrije iste delatnosti, locirane $u$ jednom regionu imaju više šansi da budu međunarodno konkurentne (italijanska tekstilna industrija, švajcarska farmaceutska industrija) nego jake industrije koje samostalno deluju u regionu. Deformisanost konkurencije, po pravilu, znači da zaštićena preduzeća traže subvencije države, što često ima za posledicu pad konkurentnosti u međunarodnim okvirima. Smatra se da industrijski klaster jednog regiona ima komparativnih prednosti samim tim što su produktivnost i veličina klastera relativno veliki u odnosu na druge regione (Porter, 2008, 184). Pristup novim, inovativnim tehnologijama olakšan je kroz udruživanje u klastere, zbog čega raste značaj i uloga klastera i sa aspekta imperativa unapređenja inovativnosti.

Najpoznatiji inovativni miljei u svetu su Silicon Valley i Boston-Massachusetts (SAD), Darmstadt i Munchen (Nemačka), Cambridge (Velika Britanija), Grenoble i Sophia-Antipolis (Francuska), Pisa i Piacenza (Italija). $\mathrm{U}$ njima je ostvarena „koncentracija inovativnih institucija" i firmi što dovodi "do stvaranja kolektivnog procesa učenja u kojem se razvoj znanja i vještina unutar jednog poduzeća ili istraživačke institucije širi na ostale aktere" (Puljiz 2011, 75). Zahvaljujući činjenici da takvu zajednicu karakterišu čvrste društvene i poslovne veze, proces kreiranja novih znanja višestruko je izraženiji. Nova znanja se ovaploćuju u inovacije proizvoda i procesa, što doprinosi kreiranju konkurentskih prednosti pojedinih regiona (Armstrong \& Taylor, 2000).

Razvoj nekog od oblika prostornih inovacionih sistema postao je jedan od prioriteta mnogih država, što je razumljivo, imajući u vidu činjenicu da se radna mesta u njima izdvajaju po produktivnosti i nivou zarada. Međutim, problem je što još uvek postoji veliki jaz između rezultata naučnih istraživanja i specifičnih saveta o konkretnim državnim intervencijama. Jedan broj analitičara, s razlogom, primećuje da se budućim istraživanjima mora proniknuti u prirodu regionalnih preduslova neophodnih za uspeh klastera (Armstrong, 1995).

Prethodno navedeni koncepti regionalnog rasta se odlikuju multidisciplinarnim pristupom u pravom smislu te reči. Računaju sa brojnim inovacijama iz oblasti privrede, administracije itd. Brojni faktori koji

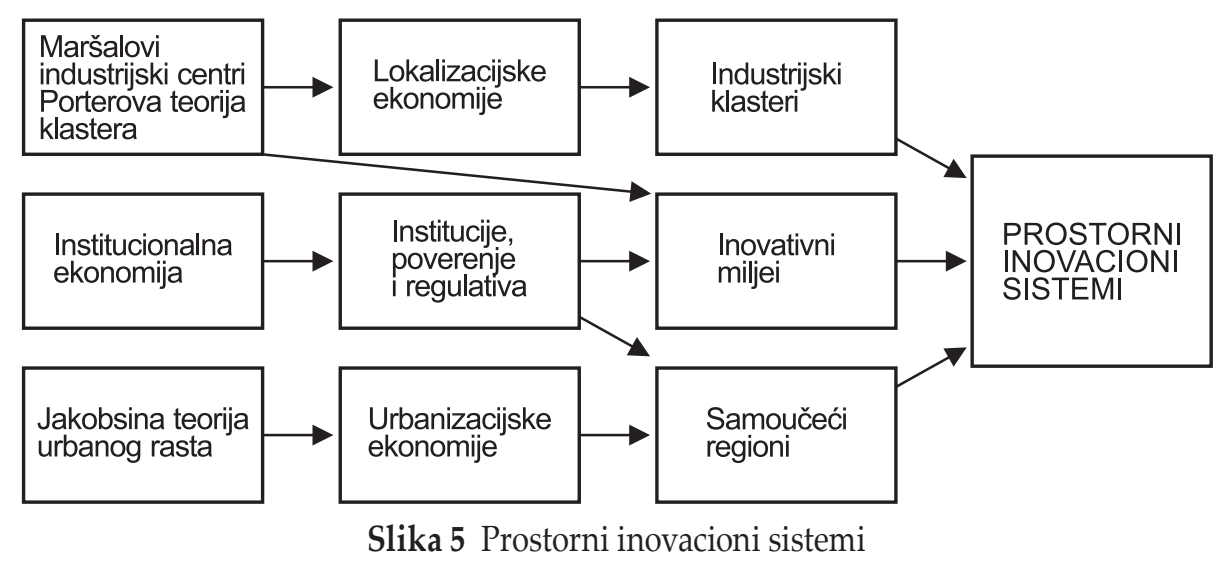

Izvor: Autori, prema: Puljiz, 2009, 40, na osnovu: Cheshire \& Malecki, 2004 
interesuju istraživače pripadaju kategoriji veličina koje nije uvek jednostavno izmeriti, poput međusobnog poverenja aktera, kvaliteta institucija, preduzetničke sposobnosti i sl. Prostorni inovacioni sistemi posebno vode računa o razvijenosti i značaju institucija, pod kojima se imaju u vidu centri istraživanja i razvoja preduzeća, univerziteta, javnog sektora a neretko, čak i politike razvoja nauke i tehnologije na nacionalnom nivou. (Puljiz, 2009; 2011).

Prethodno analizirani stavovi potvrđuju hipotezu $\mathrm{H} 0$ koja govori da savremene teorije regionalnog razvoja (teorija endogenog rasta, nova ekonomska geografija, učenje o prostornim inovacionim sistemima) akcentiraju značaj nematerijalnih faktora regionalnog rasta.

\section{NELINEARNI KARAKTER ODNOSA IZMEĐU PRIVREDNOG RASTA ZEMLJE I EKONOMSKIH (NE)JEDNAKOSTI}

Ispoljavanje nelinearnog odnosa između privrednog rasta zemlje i regionalnih nejednakosti, F. Pérroux (1955, 307-340), objašnjavao je postojanjem polova rasta. On je proces sustizanja razvijenijih od strane ekonomski manje naprednih regiona vezao za ispoljavanje efekata akceleracije i širenja razvoja. F. Pérroux se u najvećoj meri oslonio na tezu da inovativno ponašanje preduzetnika predstavlja ključ privrednog rasta (Schumpeter, 1961, 65). Dinamičan razvoj polova rasta označava $\mathrm{tzv}$. proces polarizacije, dok proces sustizanja razvijenih od strane ekonomski manje razvijenih područja označava efekat širenja razvoja. Dva su osnovna načina putem kojih se odvija polarizacija. Prvi je mehanizam nestajanja firmi lociranih u manje razvijenim oblastima, kao posledice tehnološke i organizacione superiornosti preduzeća iz razvijenijih područja. Drugi proces predstavljaju migracije obrazovanih ljudi iz manje naprednih $u$ ekonomski prosperitetnija područja. Neminovni ishod ovog procesa je smanjenje humanog kapitala kojim raspolažu manje razvijeni regioni i po tom osnovu njihovo dugoročno ekonomsko zaostajanje. Ova pojava dovodi do usporavanja privrednog rasta pojedinih regiona. S druge strane, efekti širenja razvoja javljaju se kada razvoj centra povuče za sobom i privredni rast periferije, na primer, zbog povećanja tražnje za proizvodima preduzeća iz periferije (Clunies-Ross, Forsyth \& Hug, 2009).

Dijametralno suprotno stanovište o relacijama privrednog rasta zemlje i regionalnih nejednakosti može se sresti kod neoklasičara. Najvažnija poruka neoklasičnih teoretičara odnosi se na tendenciju smanjenja razvojnih nejednakosti regiona u skladu sa napredovanjem privrednog rasta zemlje. Razvojna konvergencija regiona, po neoklasičarima, logičan je rezultat manifestacije opadajućih prinosa činilaca fizičkog kapitala i rada.

Neoklasična teorija sugeriše da lokacija nema bitniju ulogu u generisanju privrednog rasta. Za preduzetnike je, naime, po mišljenju neoklasičara, nevažno da li se radi o centralnom ili perifernom regionu, budući da oni odluke o investicionim ulaganjima donose u skladu sa očekivanim prinosima. Tvrdnja da ekonomski manje razvijeni regioni imaju izraženije stope rasta po stanovniku u odnosu na razvijenije regione, kao posledica relativno manje ispoljene tendencije opadajućih prinosa proizvodnih faktora $\mathrm{u}$ ekonomski manje razvijenim sredinama, bez uzimanja u obzir drugih momenata, $u$ teoriji i politici privrednog razvoja poznata je kao hipoteza apsolutne konvergencije. Ova hipoteza je tokom sedamdesetih i osamdesetih godina XX-og veka bila predmet brojnih provera i čestih osporavanja u ekonomskim istraživanjima (Barro \& Sala-iMartin, 2004, 56-57). Pretpostavljajući da su regioni $\mathrm{u}$ strukturnom smislu neuporedivo homogenije celine $u$ poređenju sa pojedinim zemljama, proizlazi da je teza o apsolutnoj konvergenciji primenljivija $\mathrm{u}$ analizi regionalnih nejednakosti $\mathrm{u}$ poređenju sa istraživanjem ekonomskih neravnoteža pojedinih zemalja.

Imajuću u vidu polazne premise neoklasičnih razmišljanja, logično je pretpostaviti postojanje izražene međuregionalne pokretliivosti proizvodnih faktora. U tom kontekstu, smerovi kretanja faktora kapitala i rada, determinisani su očekivanim prinosima faktora. Vlasnici kapitala će usmeravati investiciona ulaganja ka regionima $u$ kojima je 
moguće ostvariti najveće profite, dok će se radna snaga kretati ka područjima u kojima su najveće zarade. Dalji sled događaja, shodno logici neoklasične teorije, jeste da će regione sa visokim koeficijentom kapitalne opremljenosti odlikovati niski prinosi kapitala i visoke zarade. Kapital i rad će se kretati u različitim pravcima. Regioni sa nižim nivoom koeficijenta kapitalne opremljenosti rada biće potencijalno atraktivni preduzetnicima za ulaganje kapitala usled visokih prinosa, dok će regioni koje karakterišu relativno visoke zarade biti privlačni radnicima iz drugih područja. Dugoročno, mora doći do ujednačavanja odnosa između kapitala i rada (koeficijenta kapitalne opremljenosti rada) u pojedinim regionima, odnosno, do konvergencije regiona po kriterijumu vrednosti ostvarene proizvodnje po zaposlenom. Međutim, imajući u vidu činjenicu da su brojna empirijska istraživanja konstatovala rastuće regionalne nejednakosti, proizlazi da je poruka o apsolutnoj konvergenciji regiona $\mathrm{u}$ dugom roku $\mathrm{u}$ suprotnosti sa ekonomskom stvarnošću. To znači da neoklasični model rasta nije ponudio odgovarajuće smernice kreatorima politika regionalnog razvoja za prevazilaženje rastućih regionalnih divergencija $u$ okviru pojedinih zemalja.

Za neoklasičare, perfektna konkurencija i opadajući prinosi, koji oblikuju ambijent $\mathrm{u}$ kojem ekonomski subjekti maksimiziraju svoje ciljne funkcije, nikada nisu bilu dovedeni $\mathrm{u}$ pitanje. Ove teorijske postavke projektovane na fenomen privrednog rasta regiona, impliciraju stav o neminovnosti njihove ekonomske konvergencije $u$ dugom roku. Drugim rečima, ekonomisti neoklasične provenijencije smatraju da je, dugoročno gledajući, eliminisanje regionalnih nejednakosti u okviru pojedinih zemalja jedino logičan ishod razvojnih procesa tokom vremena.

Regionalna stvarnost u mnogim zemljama, međutim, bila je potpuno drugačija od ove tvrdnje neoklasičara. Naime, neretko su na delu bile izražene razvojne divergencije regiona. Spor privredni rast mnogih regiona, kao i tendencija rastućih razvojnih divergencija tokom sedamdesetih godina XX-og veka, uprkos ogromnim investicijama u povećanje fizičkog kapitala, značio je da na privredni rast regiona deluje mnogo faktora. Stoga je poruka endogenih teorija rasta da regioni u okviru posmatrane zemlje najčešće neće ostvarivati $\mathrm{tv}$. ravnotežnu stopu ekonomskog rasta i da mogu zahvaljujući delovanju endogenih faktora rasti neuporedivo intenzivnije $u$ odnosu na tzv. ravnotežni rast. Regioni ne moraju bezuslovno ekonomski konvergirati. Ispoljavanja neopadajućih prinosa faktora povezana su sa efektima tzv. učenja radom, fenomenom prelivanja znanja, aktivnostima istraživanja i razvoja, obrazovanjem kao faktorom povećanja humanog kapitala, itd. (Romer, 2006, 13; Cvetanović \& Despotović, 2014, 13).

Koncept tzv. učenja radom potiče od K. Arrow-a (1971, 131-149). Pojedinci su bolji ukoliko više proizvedu. Pojedini proizvođači uče, pored ostalog, i iz praktičnog iskustva drugih. Inkorporirajući ovo učenje, hipotezom „prelivanja znanja”, P. M. Romer (1986) je obnovio zanimanje makroekonomista za ključna pitanja ekonomskog rasta zemalja i regiona. Po P. M. Romer-u, nezavisno od činjenice „što proizvodna funkcija za svako pojedino preduzeće može imati standardnu neoklasičnu formu, na makronivou ne mora doći do ispoljavanja zakona o opadajućim prinosima. To je po njemu moguće zahvaljujući činjenici da efikasnost faktora kapitala pojedinačnog preduzeća može da raste zbog uvećanja stokova fizičkog kapitala u drugim preduzećima" (Cvetanović \& Despotović, 2014, 13). Dakle, rast fizičkog kapitala na makronivou pokreće talas pozitivnih eksternih efekata, što znači da u privredi kao celini ne mora neizostavno da dođe do opadajućih prinosa faktora (Mervar, 2003).

Aplikativnost poruka endogenih modela rasta $u$ objašnjenju regionalnih divergencija utemeljena je $u$ polazištu da su procesi prenošenja znanja značajnim delom geografski limitirani. Međuljudska interakcija, povezana sa nivoom obrazovanja stanovništva na lokalnom nivou, ima za rezultat očuvanje postojećeg i privlačenje novog humanog kapitala. Uvećanje ljudskog kapitala vodi inovacijama i privrednom rastu. Regioni najbogatiji ovim oblikom kapitala ostvaruju dominantnu poziciju $\mathrm{u}$ inovativnosti $\mathrm{u}$ poređenju sa regionima koji poseduju relativno manji obim ljudskog kapitala (Puljiz, 2011). Ekonomski manje razvijeni regioni ne predstavljaju privlačna mesta za školovane pojedince (manje zarade, 
nesigurni izvori finansiranja preduzetničkih poduhvata) predodređeni su na trajno ekonomsko zaostajanje.

Endogeni modeli rasta u zadovoljavajućem stepenu objašnjavaju razvojnu divergenciju regiona (razvijena područja više ulažu u obrazovanje, istraživanje i razvoj, u stvaranje inovacionog ambijenta). Međutim, važnija je njihova poruka o mogućoj konvergenciji, odnosno, ekonomskom sustizanju razvijenijih od strane manje razvijenih regiona, i potrebi da se najrazličitijim intervencijama regionalne politike deluje u pravcu povećanja inovacionog kapaciteta određenih teritorijalnih područja.

Po P. Krugman-u (1990), uvećanje, odnosno, smanjenje regionalnih nejednakosti određuje uticaj centripetalnih i centrifugalnih sila. Prve stimulišu koncentraciju ekonomskih aktivnosti regiona, dok druge deluju u suprotnom pravcu. Kada nadvladaju centripetalne sile, ishod su rastuće regionalne nejednakosti. Obrnuto, kada nadjačaju centrifugalne sile dolazi do ispoljavanja regionalnih konvergencija (Slika 6).

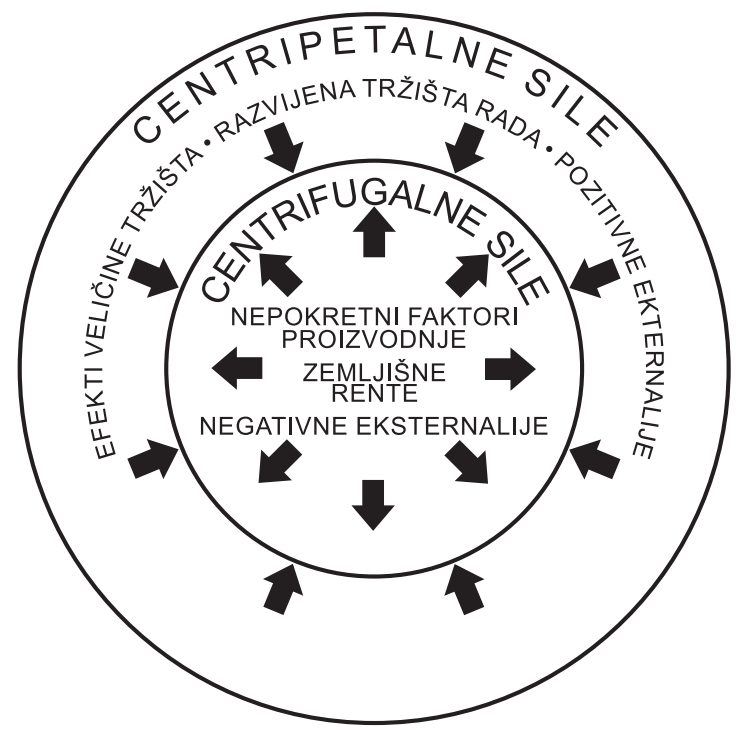

Slika 6 Centripetalne i centrifugalne sile u modelu nove ekonomske geografije

Izvor: Autori, prema: Puljiz, 2011, 71, na osnovu:

Krugman, 1990
Činjenica je, međutim, da izostaje kompetentna empirijska provera ključnih poruka nove ekonomske geografije o ispoljavanju razvojnih nejednakosti regiona. Očigledno, radi se o velikoj zahtevnosti modela nove ekonomske geografije, ne samo $u$ pogledu raspoloživosti neophodnih podataka, već i problema vezanih za formulisanje modela ekonomskog rasta regiona i kretanja regionalnih nejednakosti.

Noviji pristupi u teoriji regionalnog razvoja, označeni u ovom radu kao prostorni inovacioni sistemi, zastupaju stanovište o sve većoj regionaloj divergenciji u savremenim uslovima privređivanja. Ovo se zasniva na činjenici da se privredni rast regiona, po njihovom tumačenju, temelji na prostornoj koncentraciji visoko inovativnih firmi koje omogućavaju ne samo bliske međusobne veze, već i veze sa ostalim akterima na konkretnom prostoru. Primera radi, zahvaljujući svojoj inovacionoj superiornosti u određenim oblastima, regioni poput Silicijumske doline u SAD, Inovacionog centra Sofija Antipolis u Francuskoj, Tehnološkog parka Pretorija u Južnoj Africi, Tehnološkog parka Hsinču na Tajvanu, Centra za softverski inženjering Bangalor u Indiji, postali su simbol ekonomske moći u svetskim relacijama tokom poslednjih tridesetak godina (Smith, 2010, 266).

Prethodno eksplicirani stavovi potvrđuju hipotezu H1, po kojoj savremeni pravci u regionalnoj teoriji, u zadovoljavajućem stepenu, objašnjavaju fenomen razvojne divergencije regiona.

\section{ZAKLJUČAK}

Interesovanje za istraživanje ključnih faktora regionalnog rasta, kao i prirode i karaktera odnosa između privrednog rasta zemlje i regionalnih nejednakosti, tokom poslednjih decenija doživelo je snažnu ekspanziju. Međutim, i pored intenzivnog razvoja regionalne ekonomije, evidentno je da još uvek nema jedinstvenog stava istraživača po ovim pitanjima.

Doprinosom rada može se smatrati analiza stavova pet značajnijih pravaca u regionalnoj ekonomiji, 
po pitanjima ključnih faktora regionalnog rasta, s jedne, i nelinearnog karaktera odnosa između privrednog rasta zemlje i regionalnih nejednakosti, s druge strane. Pritom, u radu se došlo do zaključka da su viđenja predstavnika savremenih pravaca $u$ regionalnoj ekonomiji jedinstvena $u$ stavu da među faktorima regionalnog rasta dominantnu ulogu imaju nematerijalni faktori, a da razvojna divergencija regiona korespondira sa privrednim rastom posmatrane zemlje.

Osnovna i pomoćna hipoteza su kroz istraživački proces testirane i potvrđene.

Ograničenje sprovedenih istraživanja je izostavljanje kvantitativnih eksplikacija, što je u određenom smislu razumljivo, budući da je teško precizirati uticaj nematerijalnih faktora regionalnog rasta, s jedne, kao i složene odnose između privrednog rasta zemlje i ispoljavanja regionalnih nejednakosti, s druge strane.

Mišljenja smo da rezultati istraživanja mogu biti od koristi kreatorima regionalnih politika u malim i nedovoljno razvijenim zemljama, kao što je Republika Srbija, da nematerijalnim faktorima regionalnog rasta poklone veću pažnju u osmišljavanju politika regionalnog razvoja. Stoga bi dalja proučavanja mogla biti usmerena na kvantifikaciju uticaja nematerijalnih faktora na regionalni rast, kao i na preciziranje karaktera nelinearnog odnosa između privrednog rasta zemlje i ispoljavanja regionalnih nejednakosti.

\section{REFERENCE}

Armstrong, H. (1995). Convergence among regions of the European Union, 1950-1990. Papers in Regional Science, 74(2), 143-152. doi: 10.1111/j.1435-5597.1995.tb00633.x

Armstrong, H., \& Taylor, J. (2000). Regional economics and policy. Oxford, UK: Wiley-Blackwell.

Arrow, K. (1971). The economic implications of learning by doing. In F. H. Hahn (Ed.), Readings in the Theory of Growth (pp. 131-149). UK: Palgrave Macmillan. doi: 10.1007/978-1349-15430-2_11
Baldwin, J. R., \& Caves, R. E. (1997). International competition and industrial performance: Allocative efficiency, productive efficiency, and turbulence. Statistics Canada Research Paper, No 108, 31 Pages.

Barro, R., \& Sala-i-Martin, X. (2004). Economic Growth. Cambridge, Massachusettes, US: MIT Press.

Behrens, K., \& Thisse, J. F. (2007). Regional economics: A new economic geography perspective. Regional Science and Urban Economics, 37(4), 457-465. doi.org/10.1016/j. regsciurbeco.2006.10.001

Capello, R., \& Perucca, G. (2015). Openness to globalization and regional growth patterns in CEE countries: from the EU accession to the economic crisis. Journal of Common Market Studies, 53(2), 218-236. doi: 10.1111/jcms.12157

Cheshire, P. C., \& Malecki, E. J. (2004). Growth, development, and innovation: A look backward and forward. In J. G. Raymond \& M. Florax (Eds.), Fifty Years of Regional Science (pp. 249-267). Berlin, Heidelberg: Springer. doi: 10.1007/9783-662-07223-3_11

Clunies-Ross, A., Forsyth, D., \& Hug, M. (2009). Development Economics. McGraw-Hill.

Coleman, J. S. (1988). Social capital in the creation of human capital. American journal of sociology, 94, S95-S120.

Cvetanović, S., \& Despotović, D. (2014). Knowledge as the component of human capital in economic growth models. Škola biznisa, 1, 1-17. doi 10.5937/skolbiz1-5976

Cvetanović, S., Filipović, M., Nikolić, M., \& Belović, D. (2015). Endogenous growth theory and regional development policy. Spatium, 34, 10-17. doi: 10.2298/spat1534010c

Davis, D. R., \& Weinstein, D. E. (1999). Economic geography and regional production structure: An empirical investigation. European economic review, 43(2), 379-407. doi. org/10.1016/S0014-2921(98)00063-4

Dragičević, M. (2012) Konkurentnost - Projekat za Hrvatsku. Zagreb, Croatia: Školska knjiga.

Florida, R. (2002). The economic geography of talent. Annals of the Association of American geographers, 92(4), 743-755. doi: 10.1111/1467-8306.00314

Florida, R. (2004). The Rise of the Creative Class: And how It's Transforming Work, Leisure, Community and Everyday Life. (Paperback Ed.). 
Fujita, M., Krugman, P., \& Venables, A. J. (2001). The Spatial Economy: Cities, Regions, and International Trade. Massachusetts, USA: Cambridge, MIT Press Books.

Hirschman, A. O. (1988). The strategy of economic development. Boulder, CO: Westview Press.

Jakopin, E. (2012). Post-crisis reallocation of growth factors. Economic Horizons, 14(2), 79-90. doi: 10.5937/ekonhor1202077J

Jones, C. (2004). Growth and Ideas. NBER, Working Paper 10767, Cambridge, MA.

Krugman, P. (1990). Increasing returns and economic geography. Journal of Plitical Economy, 99(3), 483-499.

Kurz, H. D., \& Salvadori, N. (2001). The aggregate neoclassical theory of distribution and the concept of a given value of capital: A reply. Structural Change and Economic Dynamics, 12(4), 479-485. doi.org/10.1016/S0954-349X(01)00015-7

Kuznets, S. (1955). Economic growth and income inequality. The American economic review, 45(1), 1-28.

Lucas, R. E. (1988). On the mechanics of economic development. Journal of monetary economics, 22(1), 3-42. doi. org/10.1016/0304-3932(88)90168-7

Lundvall, B.-A. (1992). National Systems of Innovation: Toward a theory of Innovation and Interactive Learning. London, UK: Frances Pinter.

Luthans, F., Luthans, K. W., \& Luthans, B. C. (2004). Positive psychological capital: Beyond human and social capital. Business horizons, 47(1), 45-50. doi.org/10.1016/j. bushor.2003.11.007

Maskell, P. (2000) Future Challenges and Institutional Preconditions for Regional Development Policy Posed by Economic Globalisation. Possible Paths for Development: The Next 10-15 Years for the Nordic Countries in a European Perspective. In I. Karppi (Ed.), Future Challenges and Institutional Prerequisites for Regional Development Policy (pp. 27-87). Stockholm, Sweden: Nordregio Report No. 2000-1.

Mervar, A. (2003). Esej o novijim doprinosima teoriji ekonomskog rasta. Ekonomski pregled, 54(3-4), 369-392.

Molnar, D. (2013). Regionalne nejednakosti i privredni rast: Primer Srbije. Neobjavljena doktorska disertacija, Ekonomski fakultet Univerziteta u Beogradu, Beograd, Republika Srbija.

Myrdal, G. (1957). Rich Lands and Poor: The Road to World Prosperity. New York, NY: Harper.
Ottaviano, G. I., \& Thisse, J. F. (2005). New economic geography: What about the N? Environment and Planning $A$, 37(10), 1707-1725.

Pérroux, F. (1955). La Notion de Pole de Croissance. Économie Appliquée, 1-2.

Porter, M. (2008). O konkurenciji. Beograd, Republika Srbija: FEFA.

Puljiz, J. (2009). Čimbenici regionalnog razroja $i$ regionalnih nejednakosti u Republici Hrvatskoj. Neobjavljena doktorska disertacija, Ekonomski fakultet, Sveučilište u Splitu, Split, Republika Hrvatska.

Puljiz, J. (2011). Teorije regionalnog razvoja u ekonomskoj literaturi. Godišnjak TITIUS: Godišnjak za interdisciplinarna istraživanja porječja Krke, 3(3), 63-82.

Putnam, R. (2008). Kuglati sam. Novi Sad, Republika Srbija: Mediteran Publishing.

Romer, D. (2006). Advanced macroeconomics. Boston, US: McGraw-Hill/Irwin.

Romer, P. M. (1986). Increasing returns and long-run growth. The journal of political economy, 94(5), 1002-1037. doi. org/10.1086/261420

Schumpeter, J. A. (1961). The theory of economic development: An inquiry into profits, capital, credit, interest, and the business cycle. New York, NY: A Galaxy Book.

Smith, D. (2010). Exploring innovation. London, UK: McGrawHill Higher Education.

Stimson, R. J., Stough, R., \& Nijkamp, P. (Eds.), (2011). Endogenous Regional Development: Perspectives, Measurement and Empirical Investigation. Cheltenham, UK: Edward Elgar Publishing.

Todaro, M. P., \& Smith, S. C. (2015). Economic Development. London, UK: Addison-Wesley.

Trivić, N., \& Petrov, V. (2014). Determination of the economic growth rates by the growth quality. Economic Horizons, 16(2), 125-135. doi: 10.5937/ekonhor1402129T

Ulrich, D. (1998). Intellectual capital - competence x commitment. MIT Sloan Management Review, 39(2), 15.

Vazquez-Barquero, A. (2002). Endogenous Development Networking, Innovation, Institutions and Cities. London, UK: Routledge. 
Venables, A. J. (1996). Equilibrium locations of vertically linked industries. International economic review, 37(2), 341359. doi:10.2307/2527327
Williamson, J. G. (1965). Regional inequality and the process of national development: A description of the patterns. Economic development and cultural change, 13(4), 1-84.

Primljeno 14. aprila 2017, nakon dve revizije, prihvaćeno za publikovanje 23. avgusta 2017. Elektronska verzija objavljena 25. avgusta 2017.

Danijela Despotović je vanredni profesor na Ekonomskom fakultetu Univerziteta u Kragujevcu, na nastavnim predmetima Teorija i analiza ekonomske politike i Makromenadžment. Doktorirala je u oblasti makroekonomije, na Ekonomskom fakultetu Univerziteta u Kragujevcu. Oblasti njenog naučnog interesovanja su ekonomska politika i razvoj, politika unapređenja konkurentnosti, održivi razvoj.

Slobodan Cvetanović je redovni profesor na Ekonomskom fakultetu Univerziteta u Nišu, na nastavnim predmetima Makroekonomija, Ekonomija kapitala i finansiranje razvoja, Makroekonomija i makroekonomski menadžment. Doktorirao je na Ekonomskom fakultetu Univerziteta u Beogradu, iz oblasti makroekonomije. Oblasti njegovog naučnog interesovanja su makroekonomija, ekonomski razvoj, inovacije, održivi razvoj. 


\title{
THE THEORETICAL EXPLICATION OF THE FACTORS OF REGIONAL GROWTH AND THE ECONOMIC CONVERGENCE (DIVERGENCE) OF THE REGION
}

\author{
Danijela Despotovic' and Slobodan Cvetanovic ${ }^{2}$ \\ ${ }^{1}$ Faculty of Economics, University of Kragujevac, Kragujevac, The Republic of Serbia \\ ${ }^{2}$ Faculty of Economics, University of Nis, Nis, The Republic of Serbia
}

For a few last decades there has been continuous interest of economists in research of key factors of economic growth and developmental convergence (divergence) of the region. However, besides wealth of theoretical and empirical research of the mentioned categories, it is obvious that there is still no generally accepted explication of key factors of regional growth. The same conclusion can be borne in mind related to the existence of connection between the accepted economic growth of a country and tendency to increase, i.e. decrease regional inequalities. The paper presents theoretical explication of key factors of regional growth and phenomenon of developing convergence (divergence) of the region, five representative theoretical approaches in regional economy (classical, neoclassical, endogenic, new economic geography and spatial innovation systems). Current economic reality on global plan which speaks of increasing regional inequality confirms the accuracy of theoretical considerations of the representatives of contemporary theoretical approaches related to the analysed issues.

Keywords: regional economy, economic growth of region, convergence (divergence) of regional development, contemporary theories

JEL Classification: 011 